\title{
Social Media as a Destination Marketing Tool for a Sustainable Heritage Festival in Nigeria: A Moderated Mediation Study
}

\author{
Huseyin Arasli ${ }^{1, *}$, Maryam Abdullahi ${ }^{2}$ and Tugrul Gunay ${ }^{2}$ \\ 1 Norwegian School of Hotel Management, University of Stavanger, 4036 Stavanger, Norway \\ 2 Faculty of Tourism, Eastern Mediterranean University, TRNC, Via Mersin 10, Gazimagusa 99628, Turkey; \\ mam.shelia@yahoo.com (M.A.); t.gunay@cwu.edu.tr (T.G.) \\ * Correspondence: huseyin.arasli@uis.no
}

check for updates

Citation: Arasli, H.; Abdullahi, M.; Gunay, T. Social Media as a Destination Marketing Tool for a Sustainable Heritage Festival in Nigeria: A Moderated Mediation Study. Sustainability 2021, 13, 6191. https://doi.org/10.3390/su13116191

Academic Editor: Alastair M. Morrison

Received: 3 April 2021

Accepted: 19 May 2021

Published: 31 May 2021

Publisher's Note: MDPI stays neutral with regard to jurisdictional claims in published maps and institutional affiliations.

Copyright: () 2021 by the authors. Licensee MDPI, Basel, Switzerland. This article is an open access article distributed under the terms and conditions of the Creative Commons Attribution (CC BY) license (https:/ / creativecommons.org/licenses/by/ $4.0 /)$.

\begin{abstract}
This study explored how social media is used as a destination marketing tool for the sustainability of heritage festival quality in Nigeria, drawing on the theory of planned behavior. The festival, which is an exploration of heritage, was specifically premeditated to celebrate the slave trade period by highlighting the unique connection of African American history to the diaspora ancestors who were literally taken away as slaves through "the point of no return" in Badagry, Nigeria. A structured questionnaire was utilized as a research instrument to gather information aimed at examining the influence of social media (SM), website quality (WQ), and online word of mouth (eWOM) on tourists' festival satisfaction (FS) and festival revisiting intention (FRI). Data were gathered from samples of 473 diaspora tourists at Badagry Diaspora Festival in Nigeria and analyzed using partial least square structural equation modelling (PLS-SEM) with the aid of WarpPLS (7.0). The findings of the study revealed that social media (SM), festival quality (FQ), website quality (WQ), and electronic word of mouth (eWOM) had a positive and significant relationship with tourists' festival satisfaction. Additionally, this study found that festival quality had a positive impact on the intention of the tourists to revisit the Badagry Diaspora Festival because tourist attitude is influenced by the socio-cultural background of tourists. Moreover, the result revealed the partial mediating effect of festival satisfaction in the relationship between (a) SM, (b) FQ, (c) WQ, and (d) eWOM and tourists' festival satisfaction. Similarly, cultural motivation was also found to mediate the relationship between tourists' festival satisfaction and festival revisiting intension (RI). Based on the findings, the implications of the festival sustainability and future research directions were discussed.
\end{abstract}

Keywords: sustainability; heritage festival; social media marketing; African diaspora; tourism destinations; Nigeria

\section{Introduction}

Information communication technology (ICT) has been one of the most researched areas in tourism technology since the 1980s and has become one of the defining technologies of our time [1]. With the development and application of social media marketing cutting edge strategies in information technologies, tourism organizations can benefit from the numerous opportunities offered by social media to promote their relationship with their customers into a network of marketing innovations [2]. Social media marketing (SMM) presents amazing opportunities for customers to utilize the diverse platforms available, such as Facebook, Twitter, YouTube, the consumer review, blogs and networking sites, among others, to generate online content and share information about cultural tourism product and services [3,4]. This is evident in some studies that have demonstrated the importance of social media sites for marketing purposes [1,3-6], but its implications on tourism, especially, sustainability of heritage festivals, has not been exhaustively investigated. Therefore, it is important to understand how social media is used to market tourism destinations [4,6], and how consumers behave, socialize, and encourage each 
other using the new technology [7] to ensure tourism sustainability [8-10] with the related effect on the overall sustainable development $[10,11]$. Tourism destinations need to understand how to improve their social media marketing activities in order to differentiate their products and services from those of other competing tourism destinations [8,12]. Many countries regarded social media (SM) as an essential tool for promoting festivals in cultural tourism destination [13].

Cultural tourism destinations are evolving and boosting the culture and traditions of the people as a means of appealing and improving visitors' experiences. In recent times, the Nigerian government has made concerted efforts to promote "the Door of Return Festival", which was previously known as the "Badagry Diaspora Festival". The festival is a yearly event that is celebrated at Badagry, Lagos, and promoted using social media [14]. Social media has facilitated and modified communication between the diaspora communities [14]. The "Door of Return" festival in Nigeria was designed to encourage African-Americans to visit Africa, and particularly Nigeria, in order to celebrate the 400 years since the enslaved Africans who were transported forcefully to Jamestown, Virginia in the United States [15]. Meanwhile, there is need to ensure its sustainability, which has not been given adequate attention in the literature. So far, no black African nation has made rigorous efforts to offer cultural tourism products to the outside world. Examples of two famous tourist destinations in Africa are: (i) Kenya, which offers safaris; and (ii) Gambia, which markets its warm-water sea beaches. The cultural aspect of tourism is an area that is still untapped with huge potential [15].

A festival is a symbol of a cultural tourism event that can unite tourists and residents in celebrating positive motivation on their homelands in numerous ways [16]. Social media has consequently developed as a crucial network for marketing strategies to compliment these festivals [17], especially with similar heritage festivals like the "Door of Return" festival, thereby changing the way destinations communicate with their potential customers with scarce resources $[18,19]$. Furthermore, tourists believe that information that comes from a personal source is more reliable than money-spinning sources [20]. Thus, social media is particularly relevant since tourism is an "information-intensive industry" [18-20]. Social media has developed as a growing technology that has played a significant role in marketing cultural tourism products in diaspora tourism marketing [21], stimulating consumers' intentions in choosing diaspora tourist destinations. Improving their destination satisfaction depends solely on the tourists' overall satisfaction and their emotional experience is derived through the three dimensions of joy-positivity, surprise, and love $[22,23]$.

Destination managing organizations (DMOs), who are the promoters of tourism in Nigeria, are continuously faced with distinct challenges in coping with the ideal strategy to face new realities where destination branding is largely the tourist's product [7]. The unsuccessful utilization of social media by practitioners in the tourism and hospitality sectors is simply connected to a lack of practical operational skills [24]. Fortunately, social media platforms have provided a leading digital communication network $[18,20]$, with 67 percent of total internet users using a network [19]. Therefore, this disruptive digital modification has particularly affected the tourism industry [13]. It is against this backdrop that this study examined how social media is used as a destination marketing tool to promote the sustainability of the "diaspora festival" in Nigeria. This study is pertinent because the hospitality and the tourism sector is characterized as one of the leading industries being influenced by social media [21,24]. Additionally, the novelty of this article, to the best of the author's knowledge, is that there have been no empirical studies written in this area of study.

To accomplish this objective, this study employed the theory of planned behavior (TPT) and also reviewed literature of social media in the destination marketing context. The contributions of this study are threefold: First, this study contributes significantly to the literature on the sustainability of heritage festival, especially the Badagry Heritage Festival in Nigeria, which has not been previously investigated. The study will no doubt 
spell out the potential benefits of conserving the historic sites, thereby creating a sense of place and raising awareness regarding the dark periods of history amongst future generations. Secondly, the proposed model provides an insight into consumer responses, providing to valuable information to diaspora festival planners and exhibitors, specifically the Badagry Heritage Festival in Nigeria, so as to design festival products that will ensure the visitors' satisfaction with the aim of ensuring the festival's sustainability. Thirdly, the study uncovers the significance of social media as a veritable marketing tool for boosting the heritage festival's publicity. Lastly, the model developed will serve as a guide for the DMOs to implement an innovative and suitable approach for the application of satisfactory tools and procedure for achieving a sustainable Badagry Heritage Festival in Nigeria. The remainder of the paper is structured as follows: Section 2 presents the literature review and hypotheses development. The source of data and method for data analysis are presented in Section 3, while the result findings and interpretations are presented in Section 4. Finally, the discussion of findings and the implications for DMOs while identifying the limitations of the study and suggestions for further research on the subject matter are presented in Section 5.

\section{Literature Review and Hypothesis Development}

\subsection{Badagry Diaspora Festival}

Festivals are an integral part of the tourism industry, delivering unique heritage attractions for tourists, hence festivals that celebrate identities, culture, and traditions of the local community are typically referred to as significant cultural phenomena [25]. The 16th and 19th century witnessed the transportation of slaves to European countries through the slave trade roots in Badagry, Lagos, Nigeria [26]. The slave trade route is often referred to as the "Point of No Return", this is because, before the departure of slaves from Badagry, there was "a mythical well" that was enchanted to ensure that slaves who drank from it forgot their destination and were never be able to return home [27]. The festival is a "Door of Return" which is the opposite of the "Point of No Return", where a lot of people were taken out of Africa as slaves. The Badagry Diaspora Festival is a replica of the 1977 Festival of Arts and Culture, otherwise known as FESTAC 77, which stands for Second World African Festival of Arts and Culture, which was held in 1977 in Nigeria. The Badagry Diaspora Festival was designed to assist over 15 million Nigerians in the diaspora to trace their roots and reunite with their ancestry in Africa [26]. Most early deliberations of "diaspora" were firmly rooted in the conceptual "homeland", meaning Africa [26]. Findings according to the trans-Atlantic slave trade database show that about 12.8 million Africans were transported across the Atlantic, while 10.7 million were said to survive the terrifying middle passage journey to North America, South America, and the Caribbean [27]. The Badagry Diaspora Festival is a yearly event referred to as a "pilgrimage to motherland", which depicts the ancient slave trade period in Nigeria. The festival is jointly organized by the African Renaissance Foundation (AREFO) in collaboration with Agile Communications Limited, the Lagos State Government, and the office of the Senior Special Assistant to the President on Foreign Affairs and Diaspora. The festival offers a special prospect for African Diasporas and the local community to celebrate the African tradition and the remarkable history of Africans under the supervision of the UNESCO [28]. The festival ceremony displays African cultural heritage to culture lovers worldwide and the key highlights featuring at the event are creative masquerade display, fire eaters and dancers, and the beating of a Sato drum, as well as a football competition and Liberation Day celebrations to mention a few. The essence of the festival is to integrate African-Americans and Afro-Caribbean's with their ancestral home in Nigeria [29]. To successfully market the festival destination, DMOs have to make use of social media networking platforms to connect to tourists, as well as integrate the physical appearance of the consumers as a fundamental part of their leisure experience and to also maintain a strong presence in the market place as well as gain their competitive advantage [30]. 


\subsection{Festival Revisiting Intention and Theory of Planned Behavior (TPB)}

The concept of return intention comes from behavioral intention, which is defined as "anticipated or planned behavior in the future" [30]. Therefore, revisiting intention as a very powerful tool for measuring tourists' perceptions can only be understood through, predicting social behavior [31]. Visiting a festival is usually a socially evident behavior, often carried out with family, friends, and other acquaintances. This study was based on the theory of planned behavior (TPB), which has the theoretical balance for social media marketing and the concept of the diaspora festival is a good standing for a country like Nigeria, which is endowed with full tourism potential for online destination marketing. The TPB is a linkage that identifies perceived behavioral control and subjective norms, which are usually supplementary as critical antecedents beyond the evaluative attitude that effects individual behavioral intentions [32].

Many scholars in tourism, festivals, and events, including those in the social psychology field have widely and successfully used TPB to understand motivational stimulus on behavioral intentions and behaviors [33-35]. The theory of reason action was theorized to discover the relationship between views and festival revisiting intentions [35]. A number of previous studies have demonstrated the positive effect of perceived behavioral control on individuals' intentions, implying that behavioral intentions will be higher when an individual holds a decent emotional experience as it can serve as an antecedents for revisiting the festival destination $[22,34,35]$. Existing literature shows empirical evidence to support the relationship between festival quality, festival satisfaction, and festival revisiting intention [36,37]. Repeat visitation is a vital market segment for diaspora festivals and events, because it has been proven that the cost of maintaining a customer is lower than the cost of attracting first-time customers [38]. Therefore, different people have different visit preferences. Rittichainuwat and Mair [39] stated that tourists may have dissimilar motivational orientation for attending diaspora festivals and this is centered on their leisure needs. In addition, visit experience can provide visitors with an emotionally, intellectually, physically, and spiritually mixed feeling [40]. Mason and Paggioro [41] observed that the behavioral intensions of diaspora festival tourists revealed that historical appreciation, socialization, and enjoyment contribute and encourage the intention to attend a festival; this no doubt recognizes the differences among local tourists, who are concerned with socializing, and out -of-town tourists, who are tied to pleasurable moments, as shown by Choo., Ahn., and Patrick [42]. This study thus submits that festival attendees are motivated to revisit a particular tourist destination due to perceived festival quality and the satisfaction tourists derived during their visitation.

\subsection{Determinants of Festival Satisfaction}

According to United Nations World Tourism Organization, the arrival of international tourists was projected to reach 1.4 billion by the year 2020 and may generate an income of more than US\$ 1 trillion $[43,44]$. By 2030, the number of tourists is expected to reach 1.8 billion, signifying that in two decades' time, 5 million people will cross international borders for leisure, business, or other purposes, such as visiting friends and family, every day, besides the four times as many tourists traveling domestically [45]. Meanwhile, the outbreak of the coronavirus (COVID-19) has dealt a great blow to the international tourist market, which as at 2020 has fell short of the projected 1.4 billion by $20 \%$ [46]. Gossling et al. [47] observed that most economies around the world depend on Nigerian tourism sector as their backbone, which corroborates the fact that Nigerian tourism represents $9 \%$ of global trade for tourism in Africa [48]. Consequently, tourism is the fastest only significant and industry that improves the world economy and DMOs depend on tourists/visitors to support the economy [22,49-51].

Westbrook and Oliver defined tourists' satisfaction as the post consumption assessment of a definite product or service. This can also be seen as the totality of a tourist's attitudes towards a vacation experience, which is considered as a key decision in a tourist's choice of tourism services [23]. The theory of planned behavior (TPB) has delivered sup- 
portive suggestions regarding social media marketing, festival quality, website quality, online word of mouth (eWOM), festival satisfaction, cultural motivation, and festival revisiting intention. This shows that the majority of research relating to digital technology focused solely on customer satisfaction in providing quality tourism services to tourists at many cultural destinations [22,50,52]. Therefore, value creation has been measured as a key to long-term success [53]. Likewise, the DMOs have been identified as providers of festivities and celebrations, reacting to the needs of diaspora communities in terms of their cultural heritage [52]. Badagry Diaspora Festival has played a vital role in the local representation of diaspora cultural events by connecting tourists and the local inhabitants in celebration [16,52]. The collective experience shared is part of the diaspora festival "product", which makes is particularly relevant in the investigation of social media usage settings. Literature has suggested that diaspora festival cultural experiences are mediated by increasingly innovative social media activity for tourists' satisfaction [54]. As such, the theoretical communication model of this study is based on social media marketing, festival quality, website quality, e-word of mouth through the mediation of festival satisfaction, and moderation of cultural motivation via revisiting festival intention. The variables will enable DMOs to understand the key variable needed to interact with tourists, who have the main potential to promote the festival destination by offerings key social factors to festival promoters [55].

The benefits of participation in online social media networks include the usage of different social media tools and intention to exchange relevant information with consumers. The factors to consider include tourists' insight, travelers' involvement in understanding opinions on social networking site using pictures, video, social capital and feelings of involvement [56], networking websites, blogs, and other online mediums that are opportunities for diaspora festivals to facilitate these social psychological benefits and foster social group belonging, which could lead to repeat visitation [57]. However, much of social media literature has focused on Facebook and on tourism industries outside festivals, particularly DMOs [58-61].The diaspora festival and social media tools both aim to build local community [62] and many tourism practitioners are beginning to offer social media applications to festivalgoers, an approach that could give rise to economic revitalization. The Door of Return festival destination in Nigeria is determined to advance its cultural capital to encourage international tourist visitation. Many research studies have revealed that most visitation to online tourism destinations is focused mainly on the economic impacts of the destinations. Hence, the benefits of diaspora festivals are demonstrated more explicitly in peripheral rural areas, particularly in boosting local economics, creating employment opportunities. and promoting local culture and products [63]. Although, diaspora festivals mostly take place in rural areas and are usually small in scale, they boost the tourism destination or can support a varied plethora of themed programs $[64,65]$.

\subsubsection{Social Media Marketing as a Determinant}

The Internet and social media are two of the most significant communication networks shaping the festival brand awareness to tourists [66]. Within the 21st century, social media has advanced as an essential and indispensable part of promotion and communications technology for tourism organizations $[19,67]$. Social media networks are platforms that DMOs utilize in the marketing and promotion of cities, states, and nations [68]. It is a platform for social interaction set beyond social communication and distributing information to tourists about a destination. Social media is altering the way DMOs consume and contribute their thoughts, opinions, and creations in the marketing of festival products through the internet. This has, however, distorted the way information is created and circulated for tourist consumption [60].

African-Americans and diaspora tourists search for information about Badagry Diaspora Festival, which is provided by the DMOs, through social media networking sites. For example, Lye and Hwang [69] found that travelers used social media network services to reduce the high demand from tourism information centers (TICs) by $27.4 \%$. There are enor- 
mous amounts of tourism information provided online, but only a very small proportion can be accessed by tourists [60]. The Door of Return festival in Lagos, Nigeria, is relatively new and DMOs are struggling to make their information visible to potential tourists. Social media is a crucial platform for marketing of tourism destinations, where festivals are seen as a deeply embedded movement of peoples heritage. It has been revealed that 88 percent of marketers are using social media and that they are spending over $\$ 60$ billion annually on social media advertising [70,71]. It has been also estimated globally, that the total number of social media users will grow to 3.29 billion users in 2022 , representing $42.3 \%$ of the world's populace [72]. Social media in the 21st century appears to be the most pertinent means through which tourism destinations communicate and interact with consumers $[19,73]$. Tourism destinations are regarded as places where individuals travel and decide to remain for a specific period of time [60]. Destination marketers need to know why and how tourists participate in social media events to have a strong presence on their platforms.

In the literature, two crucial reasons for the rise and acceptance of social media among tourism traveler were identified. Firstly, it has been observed that the nature of tourism products permit potential tourists to depend upon shared experiences on social media platforms during decision making. Interestingly, the evidence provided in online groups can be perceived by some customers as equivalent information they obtain from members of family, friends, or "like-minded souls" [74,75]. Secondly, Gretzel et al. [76] established that social media allows travelers to tell their stories uninterrupted on a " $24 / 7$ " basis and this storytelling in turn improves the cleverness of fitting into online tourists' platforms.

Likewise, destinations are understood by visitors to mean exclusive places where amenities and services are planned to meet the desires of the visitors. Social media has no doubt improved the traditional communication strategies of classical marketing [24]. Hence, current campaigns and investigations suggest that a limited number of tourism destinations are beginning to study social media and develop strategies to use at their advantage [23]. The study of Osei et al. [3] revealed that international tourists employed social media as a valuable travel decision tool to visit Ghana. Hudson et al. [77] also reported that social media has had a crucial impact on emotions and attachment of festival brands offering positive word of mouth. Similarly, during the pre-travel period, potential travelers utilized social media for motivation, using social media platforms like YouTube and blogs to produce images of the future destination and also communicate with consumers. Moreover, travelers' memorable experiences before and after travel are being shared in the form of videos and photos on platforms like Instagram and Facebook. Tourism products are sold well in advance before consumption. Tourists' decisions in purchasing cultural festival products basically depend significantly on positive stories and electronic word of mouth (eWOM) told by tourists through sites such as Facebooks and TripAdvisor. the utilization of social media in the tourism industry appears to be sensitive in nature in terms of countless mediated tourism experiences [7]; The dissemination of consumergenerated content (CGC) on social networking sites, blogs, and video portals offers actual and potential consumers trusted information about the destination from other consumers, which empowers consumers to share independent views and spread their satisfaction or dissatisfaction with the diaspora cultural festival products [60].

Thus, social media creates spaces for socializing and connecting with friends and relations [77]. Tourism destinations have enormous opportunities to encourage the development of supply and demands sides through the social media. So, therefore we posited that:

Hypothesis 1 (H1). Social media has a positive and significant relationship with tourists' satisfaction.

\subsubsection{Festival Quality as a Determinant}

Quality is significant for diaspora festival destinations trying to determine their tourism production standards in relation to a product/service. It is also important because it positively affects consumers' attitudes and future behaviors toward the tourism desti- 
nation [78]. Perceived quality signifies superiority or excellence of a product or service as expected by customers $[78,79]$. Further, quality shows the performance of a particular product or service $[79,80]$. The first to start the conceptualization of festival quality measures were Crompton and Love [81]. Their postulations were that if a diaspora festival sustains a high level of quality, then there will be a more satisfied attendee. In addition, quality perception can diversify the products of the diaspora festival, which can lead to tourists' positive attitudes toward the festival quality in the tourism destination [82]. It is, however, a more logical approach for DMOs to specify the quality level of products and services on social media platforms to enhance the festival quality and increase sales by taking all the necessary actions to entice African-Americans and other diaspora, because perceived experience quality is recognized based on specific standards and results $[83,84]$.

The key component of any festivals' attributes is the evaluation of festivals by attendees. Therefore, to provide a successful experience for tourists, quality remains a very important element for the survival strategy of any business; one basic requirement is to deliver a superior quality to consumers $[79,85]$. The increased visitation and revenue generation at a diaspora festival destination can only be gained through improved festival quality as a supporting element for competitive advantage [79]. Similarly, Wong et al., [86] found that the components of festival quality include interaction quality, physical quality, outcome quality, access quality and programmed quality, respectfully. Based on the aforementioned reviews, festival quality has been considered to be a multidimensional construct. Understanding diaspora festival attendees' experiences is imperative to diaspora festival management because attendees' satisfaction directly influences the future of the diaspora festival. Tourism is one of the unexploited areas of development opportunities in Nigeria. Therefore, Badagry Diaspora Festival is required to deliver a high-quality experience to festival attendees in order to successfully fulfil their desires. It is assumed that a favorable evaluation of overall perceived quality should result in a positive affective impact response [85,87]. It is also commonly believed that high level of quality will generate satisfied attendees who are more likely to spread positive or negative word of mouth, and to be repeat or one-time attendees, respectively [88]. Therefore, the following hypothesis was proposed:

Hypothesis 2 (H2). Festival quality has positive and significant relationship with tourist satisfaction.

\subsubsection{Website Quality}

Park, Gretzel, and Sirakaya-Turkb [89] defined perceived website quality as the customers' general judgment about the superiority and preponderance of a website. Safeguarding high ranks of website quality facilitates and encourages satisfaction levels and customer loyalty in persuading great repurchase behavior, thereby spreading/stimulating e-WOM in generating benefits derived from online destination marketing [90]. In leisure and tourism management, the significance of evaluating websites has been pointed out $[89,91]$ and same is applicable for hotels [92] and the reservation centers for travel and tourism [93], including the online travel organizations [89]. The quality of websites is assessed base upon evaluating concepts [94], or the influence of the site [95]. The idea of website quality arises from the necessity to adjust the typical beginning of service quality and its modeling to SERVQUAL dimensions (tangibles, reliability, responsiveness, assurance, and empathy), paying attention to the perspectives where the customers interact to a larger extent with digital fundamentals as a substitute directly to the service staff [96].

The Nigerian government proposed a web-based expert design decision, which was designed to furnish the tourism destination marketing organization (DMOs) with the understanding that can enhance their ability to enrich tourists with valuable social media information that can help tourists interact with tourism destinations through the usage of data processing. Hence, this system allows the tourists to reach a personal judgment regarding using the artificial intelligence techniques in solving problems [97]. 
Tourism destination websites are seen as a crucial promotional tool for cultural tourism festivals $[98,99]$ and a destination website is capable of creating digital video experiences that encourage the user behavior and intention to revisit tourism festival destinations [91,100]. Online cultural festival marketing advancement has improved website quality in Nigeria. Hence, the quality of website design is a very significant factor for DMOs to attract tourists [99]. For DMOs, it is critical to keep a strong bilateral communication plan with online customers. The natural experience of tourism and the quick development of online networks, together with a greater tendency to share information on behalf of the tourists, have generated a framework where one learns from the experiences of others when deciding on a destination [101]. Tourist behavior in terms of creating, sharing, and disseminating information has been analyzed by platforms such as travel websites [102], blogs [101], or social networks [103,104]. Nevertheless, there is still a persistent need to look into the impact of content created by tourists through e-word of mouth (e-WOM).

However, cultural tourism marketing websites are new in Nigeria, and most consumers are still inexperienced in using social media for buying festival products [105]. A well-designed website should be easy to use, easy to navigate, and user friendly. The Lagos State Ministry of Tourism, who are the DMOs in collaboration with the Ministry of Foreign Affairs, set up a website for marketing of the Badagry Diaspora Festival in Nigeria. The website provides not only informational support, but also content created by visitors through tagging, integration, and sharing of information via social media platforms, like Facebook, Twitter, Instagram, Pinterest, among others is performed [97].

In addition, most destination marketing websites allow users to engage and have online experiences about the festival destination in order to reach both local and international tourism demands and forecasting tourists' arrivals [106].

Previous studies on quality websites revealed that social media purchasing behaviors of tourists vary based on website user friendliness and online purchasing behavior and tourist perception about the tourism products [107]. Tourists' satisfaction through the application of quality website enhanced profit and market share. This assertion is in harmony with [108], which stated that DMOs harbor the same idea that social media platforms are for marketing festival destination products, which enhances market promotion and also helps target the tourist market. Similarly, DMOs are becoming more and more conscious of the significance of creating added value to tourists' memorable experiences $[109,110]$. This finding is in harmony with the assertion of Novaise Ruhanen, Arcodia [111] who stated that festival destinations must provide adequate visitors facilities and services that can be a thrilling experience for tourist satisfaction. Alizadeh et al. [68] also clearly pointed out that one of the challenges of destination marketers is coordinating the activity of social media marketing via expert diaspora festival marketers. However. They emphasized that website quality has a positive and significant effect on the consumer's choice of tourist products, as well as developing a sense of trust and value in potential customers. Based on this outcome, the third hypothesis was formulated. To this regard this study posed that:

Hypothesis 3 (H3). Website quality has a positive and significant relationship with tourists' satisfaction.

\subsubsection{Electronic Word of Mouth (eWOM) as a Determinant}

Since the evolution of the internet as a world wide web (WWW) in the early 1990s, there has been a tremendous increase in the number of DMOs trying to carry out the importance of eWOM [112]. Through eWOM, a close relationship has been designed for marketing festival destinations by saving time at a cheaper rate. Lately, the WWW has been utilized as a new marketing medium for eWOM, as well as serving as a means of disseminating information for customers, both friends and relations [113].

Online WOM is referred to as "any positive or negative statement voiced by a potential, actual, or former customers regarding a tourism product [114], which is put across to high 
number of consumers via the social media" [115]. It signifies informal communications technology (ITC), done through the internet, with regards to the structures of certain services and their retailers [116]. The rising acceptance of online social media interaction services by clienteles and businesses calls for novel information in order to understand their influence on consumer behavior, and more significantly, how eWOM happening through these platforms effects the decisions of the consumer [117]. eWOM has the advantage of attracting several customers with scarce resource and high effectiveness [118]. Marchand, HennigThurau, and Wiertz [119] examined the social networks and their variable websites, digital games, and WOM and resolved that WOM was the most active in social networks because it has extensive applications with a high number of followers or a large audience.

As more and more diaspora festival marketers are integrating social media as part of their promotional mix, rigorous examination on the factors that influence consumers' engagement in eWOM via social networking sites is increasingly becoming critical [120]. Traditional word of mouth forms of publicity and communication are gradually losing their efficacy to digital word of mouth due to lack of consistency and uncertainty of trustworthiness [121,122]. Thus, tourists search for relevant information before making a decision to visit diaspora festival destinations or purchase tourism products and services on destination website settings $[123,124]$. Marketing scholars have indicated that eWOM has an effect on tourists' behavior and buying decisions in relation to choice and satisfaction [125]. Tourism products are sold in advance of consumption, and decision making in purchases relies significantly on positive stories and electronic word-of-mouth (eWOM) via sites such as TripAdvisor and Facebook. It should be noted that in the context of creative promotion, such as the case of the Badagry Diaspora Festival, managers are seen as being in a key position to compose the festival experience and the festival brand name [126]. Previous studies, as revealed by some tourists, stated that positive WOM about visiting a festival destination through the website can be one of the unfailing and influential sources of information that can inspire potential tourists to make a travel decision [127].

Furthermore, Haussmann [128] maintained that e-WOM is an effective means of gaining referrals in applications such as Facebook and Twitter, making it possible to reach an unlimited number of consumers. In the context of festival reputation and e-WOM, if consumers do not trust the destination through negative eWOM, they are unlikely to take the risk of visiting the tourist destination. Thus, the tourism sector is sensitive to the countless mediated tourism experiences revealed through negative eWOM experience [7].

Revisiting a tourist's destination can only be achieved through satisfied tourists who may recommend the destinations to others. Therefore, dissatisfied tourists may express negative comments about a destination and damage the destination's market reputation $[10,129]$. Baker and Crompton [36] suggested that festival managers should focus their evaluative resources on assessing both festival quality and satisfaction level of attendees. In festival management studies, Lee et al. [130] and Wu et al. [79] considered festival quality as a key factor in influencing festival satisfaction. Therefore, this study posited that:

Hypothesis 4 (H4). eWOM has a positive and significant relationship with festival satisfaction.

\subsection{Festival Satisfaction and Revisiting Intention}

According to Abbott [131] "what people really want are not products but satisfying experiences. Satisfaction is a crucial factor in marketing of tourism and diaspora festival literature, where public and private organizations at all geographical levels are attempting to use tourism, festivals and events alike as a tool for reshaping their respective cultural identities [132]. Satisfaction is described in the literature as "the consumer fulfillment response", a post consumption judgment by a consumer that a service provides a pleasing level of consumption-related fulfilment, including under or over-fulfilment [132]. Specifically, festival satisfaction has been operationalized as overall satisfaction, since satisfaction in this study was based on overall festival effective impact evaluation by the composite 
of the quality dimension of the festival $[80,86]$. Therefore, satisfaction is fundamental to organizations' promotional activities $[133,134]$, hence, the "measuring and management of customer satisfaction is pivotal for the survival, growth, and success of tourism as a service industry" [134]. Tourists' positive experiences with diaspora festivals is expected to strengthen their individual satisfaction, which is likely to contribute more to their general quality of life and independent well-being [135]. Tourist satisfaction can be affected by tour quality, tour price, and interaction between them [136]. Festival attendees are inclined to believe that products in high demand have high quality and thus become more certain in revisiting a tourist destination [137]. To date, the current research has not captured the influence of festival satisfaction. To this regard, this study declared that:

Hypothesis 5 (H5). Festival satisfaction has a significant and positive relationship with festival revisiting intension.

\subsection{Mediating Effect of Festival Satisfaction}

Relevant literature in tourism revealed that online destination marketing on festival revisiting intention can either have full or partial mediation with festival satisfaction. This may have direct or indirect effects on both the local and international tourists who have intentions of visiting the diaspora festival in the future. To evaluate the mediating role of festival satisfaction between dimensions of festival quality and tourists' revisiting intention toward the Badagary Diaspora Festival in Nigeria, mediation conditions of Baron and Kenny [138] were employed in the present study. The laid down conditions were: (a) predictor must have a significant effect on the result of the variable; (b) it is essential that the predictor must have a significant effect on the mediator; (c) the outcome of the variable must be significantly affected by the mediator; (d) lastly, after introducing the mediating variable between the predictor and outcome variable, the direct impact of predictor on outcome becomes insignificant (full mediation). Nevertheless, if the direct effect is lessened, then it is measured as partial mediation. Additionally, in order to observe the aforementioned standards, only those dimensions of festival satisfaction were considered in the mediation model, which appeared to have a significant impact on diaspora festival revisiting intentions based on the cultural motivation of the festival destination [139]. Thus, we hypothesized the following:

Hypothesis 6 (H6). Festival satisfaction mediates the relationship between (a) social media, (b) festival quality, (c) website quality, and (d) eWOM and festival revisiting intension.

\subsection{Moderating Role of Cultural Motivation}

According to the Federal Ministry of Information and Culture, the Nigerian government lunched a "National Cultural Policy", which defined culture as "the totality of the way of life evolved by a people in their attempt to meet the challenges in their environment which gives order and meaning to their social, political, economic, aesthetic and religious norms and modes of organization, thus distinguishing a people from their neighbor" [140]. Likewise, cultural motivation is defined as a general interest in exploring the culture, history, and heritage in the context of cultural tourism [141]. There is lack of consensus among researchers with respect to the dimensions of tourists' travel motivations, as these differ with respect to different destinations and tourists' sociodemographic characteristics. Earlier studies have explored two dimensions/factors of travel motivations, that is, push and pull factors $[133,142]$. The push motivations have been useful in explaining the desire for travel, while the pull motivations help illustrate the actual destination choice [143]. Therefore, understanding the effect of social media on diaspora festival attendees' travel motivation has played a central role in the search for the importance regarding the meaning of modern life, which is recognized as a motivational factor in leisure and tourism [144].

The findings of the moderating role are in harmony with the two studies illustrated as example of mixed conclusions regarding the impact of cultural motivation on diaspora 
festival destination choice. Jackson [145] reported that people from highly individualistic countries (e.g., USA) tend to choose culturally similar destinations, while those from highly collectivistic countries (e.g., Korea) tend to choose culturally distant destinations. Hence it is presumed that considering the cultural ties African-Americans have with Africa marketing diaspora festival Badagry will be of interest to them. Similarly, Nigeria as the giant of black Africa, the richest, most populous, and most advanced nation in black Africa is highly gifted with outstanding cultural attractions, representing a rich and varied heritage which, if scientifically marketed, using the social media could draw millions of "Lovers of Black Beauty" [15]. In the festival-growing market, the success of tourism destination marketing is focused on detailed analysis of tourists' cultural motivations and the interplay in tourists' revisiting intentions [146]. Therefore, it can be deduced that the positive effect of value on satisfaction can be construed from logic that value creates satisfaction [147]. Additionally, social media provides DMOs with the media opportunity to provide customized products and services to African-Americans and the diaspora [148]. A growing body of knowledge recognizes that tourist behavior is influenced by the sociocultural background of tourists [149]. Hence, we posited that:

Hypothesis 7 (H7). Cultural motivation moderates the positive relationship between festival satisfaction and festival revisiting intension.

As depicted in Figure 1, the theoretical research model is built on many relationships. Social media marketing, festival quality, website quality, and e-word of mouth influences information with full moderated mediation on cultural motivation and tourists' satisfaction through festival revisiting intention. The control variables include age, gender, marital status, education background, and nationality, which a have crucial impact on the relationships between the variables mentioned in the study.

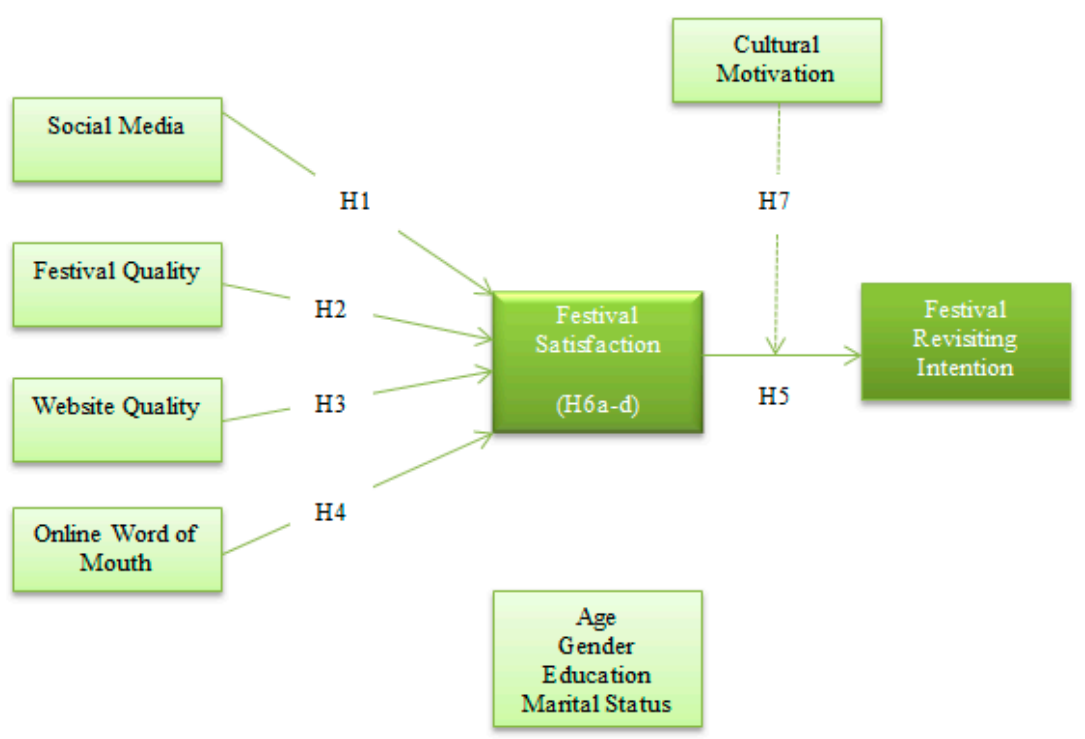

Figure 1. Theoretical research model.

\section{Methodology}

\subsection{Sample and Procedure for Data Collection}

The main focus of this study was on the Badagry Diaspora Festival, which is also tagged "The Door of Return Festival". The event is a yearly event, taking place in Badagry Lagos, Nigeria. Therefore, the quantitative method was employed to collect data during the festival. This research was conducted during the Door of Return Festival in Badagry Nigeria. The survey method used was complemented with the observation of the DMOs' official website to examine the DMOs' use of social media in communicating with their potential tourists/customers. Hence, we observed the presence of the DMOs' websites and 
the activities of social media on their website from 20 August 2019 to 19 October 2019 to achieve the aim of this study. The result of the observation revealed that Facebook was the most used social networking site by the DMOs. This affirms the presence of the DMOs on social media. Moreover, we used a questionnaire as an instrument for data collection to investigate the main study aim. We administered the questionnaire during the festival to ascertain first-hand information from the tourists. The questionnaire was structured and comprised two components, demographic information and construct-specific questions. We used a 5-point Likert scale, ranging from strongly disagree to strongly agree. The constructs and the items were adopted from previous studies discussed in the literature review [79,150-152]. Owing to the absence of a comprehensive list of the visitors to the festival, this study followed the suggestion of Cochran [153] in choosing the sample size. The following formula was then applied: $n_{0}=z^{2} \frac{p q}{e^{2}}$, where $n_{0}=$ sample size, $\mathrm{z}=$ confidence level desired, $\mathrm{p}=$ population variability, $\mathrm{q}=1-\mathrm{p}$, and $\mathrm{e}=$ level of precision. Thus, with maximum variability of $50 \%, 95 \%$ confidence level, and adoption of $\pm 5 \%$ confidence level as the precision level, the sample size needed to be:

$$
\text { Sample size }=1.96^{2} \frac{(0.5)(0.5)}{0.05^{2}}=384.16
$$

Consequently, 500 questionnaires were administered using a convenient sampling technique and 473 questionnaires were retrieved representing (94.6\%) for analysis in this study. Convenient sampling technique is a type of nonprobability sampling procedure that involves a sample being drawn from a group of people easy to contact or reach. It should be noted that every participant stands an equal chance of filling in the questionnaire as long as the respondent is an adult (from 18 years and above).

One of the basic criteria used for filling the questionnaire was that three trained research assistant were positioned at the entrance of the festival to identify both international and domestic tourists to give their consent in filling the questionnaire. All respondents were assured of their confidentiality. Convenience sampling was used because the festival is held for a few days once in a year (from 15-20 October 2019), and the participant population is unknown. Since the population gathers once in a year, we needed to obtain the data within the shortest possible time. Hence, convenient sampling technique became handy. Also, any available visitor to the festival can provide relevant information concerning the study.

\subsection{Instrument for Measurement}

We followed established and validated measurements of each construct obtainable in the extant literature. Accordingly, we measured the variable (construct) representing social media with five items recommended by Icoz et al., [152] while festival quality was measured using eight (8) items adopted from Wu et al., [79]. Furthermore, we adopted the measurement of Wan and Chan [153] to capture festival satisfaction with eight (8) items, while we measured revisiting intention through four (4) items adopted from Bigne, Sanchez, and Andrew [150]. Table 1 discussed the demographic profiles of the respondents. The detailed statement of each item in all the constructs is presented in Table 2. The data were analyzed using partial least square structural equation modeling (PLS-SEM).

\subsection{Data Analysis}

IBM's SPSS Statistical Tool was used to prepare the data and analyze the demographic characteristics of the respondents. Meanwhile, in order to establish the relationships proposed in the model, partial least square structural equation modeling (PLS-SEM) was employed. The WarpPLS $7.0[10,154]$ was utilized to analyze the model structure of this study. According to Kock [155], WarpPLS is "a partial least square regression procedure that is effective for analyzing both linear and non-linear relationship simultaneously" [10]. PLS-SEM is believed to be efficient in testing the relationship between constructs and results in predictions that reflect the complexity of real-life situations [10]. In addition, it is efficient in addressing a small sample because of its non-dependence on data normality [154]. 
Table 1. Respondents' characteristics.

\begin{tabular}{|c|c|c|c|}
\hline Gender & Frequency & Valid Percent & Cumulative Percent \\
\hline Male & 251 & 54.6 & 54.6 \\
\hline Female & 209 & 45.4 & 100.0 \\
\hline Total & 460 & 100.0 & \\
\hline \multicolumn{4}{|l|}{ Mstatus } \\
\hline Single & 248 & 54.0 & 54.0 \\
\hline Married & 175 & 38.1 & 92.2 \\
\hline Separated & 27 & 5.9 & 98.0 \\
\hline Divorced & 9 & 2.0 & 100.0 \\
\hline Total & 459 & 100.0 & \\
\hline \multicolumn{4}{|l|}{ Education level } \\
\hline Primary School & 21 & 5.0 & 5.0 \\
\hline Secondary School & 118 & 28.4 & 33.4 \\
\hline Bachelor Degree & 171 & 41.1 & 74.5 \\
\hline Master's Degree & 82 & 19.7 & 94.2 \\
\hline Doctoral Degree & 24 & 5.8 & 100 \\
\hline Total & 416 & 100.0 & \\
\hline \multicolumn{4}{|l|}{ Occupation } \\
\hline Professional & 82 & 17.7 & 17.7 \\
\hline Government Employee & 60 & 13.0 & 30.7 \\
\hline Private sector employee & 40 & 8.7 & 39.4 \\
\hline Self-employed & 92 & 19.9 & 59.3 \\
\hline Business owner, House wife & 21 & 4.5 & 63.9 \\
\hline Student & 147 & 31.8 & 95.7 \\
\hline Retiree & 20 & 4.3 & 100.0 \\
\hline Total & 462 & 100.0 & \\
\hline \multicolumn{4}{|l|}{ Timevisited } \\
\hline Once & 154 & 33.6 & 33.6 \\
\hline Twice & 159 & 34.6 & 68.2 \\
\hline Three times & 90 & 19.6 & 87.8 \\
\hline Four or more times & 56 & 12.2 & 100 \\
\hline \multicolumn{4}{|l|}{ Nationality } \\
\hline African Amerıcans & 39 & 8.25 & 8.21 \\
\hline Benin & 16 & 3.38 & 11.63 \\
\hline Canada & 1 & 0.21 & 11.84 \\
\hline Coast Orica & 1 & 0.21 & 12.05 \\
\hline Ghana & 24 & 5.07 & 17.12 \\
\hline Haiti & 1 & 0.21 & 17.34 \\
\hline Jamaica & 1 & 0.21 & 17.55 \\
\hline Nigeria & 364 & 76.96 & 94.50 \\
\hline South Africa & 1 & 0.21 & 94.71 \\
\hline Togo & 23 & 4.86 & 99.58 \\
\hline UK & 1 & 0.21 & 99.76 \\
\hline Uganda & 1 & 0.21 & 100.00 \\
\hline TOTAL & 473 & 100.00 & \\
\hline
\end{tabular}


Table 2. Reliability and validity of measurement scales.

\begin{tabular}{|c|c|c|c|c|c|}
\hline Constructs(Dimensions) and Items & Factor Loading & AVE & CR & Cronbach's Alpha & FVIF \\
\hline Social media Marketing & & 0.724 & 0.894 & 0.922 & 2.227 \\
\hline $\begin{array}{l}\text { Social networking sites provide reliable information about } \\
\text { Badagry Diaspora Festival. }\end{array}$ & 0.662 & & & & \\
\hline $\begin{array}{l}\text { I subscribe on the social networking sites about } \\
\text { festival destinations }\end{array}$ & 0.827 & & & & \\
\hline $\begin{array}{l}\text { Social networking sites contribute to the promotion of } \\
\text { festival destination. }\end{array}$ & 0.826 & & & & \\
\hline $\begin{array}{l}\text { I use social media to access the websites of the } \\
\text { festival destination }\end{array}$ & 0.873 & & & & \\
\hline $\begin{array}{l}\text { I make use of the posts and the comments of the people on } \\
\text { social networking sites about the festival destination. }\end{array}$ & 0.878 & & & & \\
\hline $\begin{array}{l}\text { Positive comments of the users on social networking sites } \\
\text { make me trust the festival as a tourist destination. }\end{array}$ & 0.837 & & & & \\
\hline Festival satisfaction & & 0.570 & 0.852 & 0.815 & 2.352 \\
\hline The location is accessible & 0.680 & & & & \\
\hline Varieties of food are available & 0.754 & & & & \\
\hline Venue facility is comfortable & 0.717 & & & & \\
\hline The environment is beautiful & 0.739 & & & & \\
\hline The services offer is satisfactory & 0.682 & & & & \\
\hline The festival attracts huge population & 0.196 & & & & \\
\hline Adequate entertainment is provided & 0.653 & & & & \\
\hline The timing of the festival is convenient & 0.674 & & & & \\
\hline Revisiting intention & & 0.691 & 0.826 & 0.855 & 2.258 \\
\hline $\begin{array}{l}\text { I will continue to visit the Badagry Diaspora Festival in the } \\
\text { near future. }\end{array}$ & 0.767 & & & & \\
\hline $\begin{array}{l}\text { I consider the Badagry Diaspora Festival as my first choice } \\
\text { compared with other festivals and events. }\end{array}$ & 0.695 & & & & \\
\hline $\begin{array}{l}\text { I have a strong intention to visit the Badagry Diaspora } \\
\text { Festival in again. }\end{array}$ & 0.801 & & & & \\
\hline $\begin{array}{l}\text { Revisiting the Badagry Diaspora Festival as would be } \\
\text { full of fun. }\end{array}$ & 0.681 & & & & \\
\hline Festival quality & & 0.620 & 0.916 & 0.914 & 2.749 \\
\hline The festival has product diversity & 0.722 & & & & \\
\hline The cost of visiting the festival destination is affordable. & 0.704 & & & & \\
\hline There are professional staff & 0.785 & & & & \\
\hline The festival destination provides clean environment & 0.731 & & & & \\
\hline The design of the festival is good & 0.815 & & & & \\
\hline The location of the festival is conducive & 0.808 & & & & \\
\hline The festival offers Sufficient facilities & 0.744 & & & & \\
\hline The festival is well plan and organized & 0.761 & & & & \\
\hline
\end{tabular}


Table 2. Cont.

\begin{tabular}{|c|c|c|c|c|c|}
\hline Constructs(Dimensions) and Items & Factor Loading & AVE & CR & Cronbach's Alpha & FVIF \\
\hline Online word of mouth & & 0.797 & 0.915 & 0.914 & 1.658 \\
\hline $\begin{array}{l}\text { I will report positively about the Badagry Diaspora Festival } \\
\text { to other people. }\end{array}$ & 0.857 & & & & \\
\hline $\begin{array}{l}\text { I will recommend the Badagry Diaspora Festival to others } \\
\text { who seek my advice. }\end{array}$ & 0.892 & & & & \\
\hline $\begin{array}{l}\text { I will encourage my friends and relatives to visit the } \\
\text { Badagry Diaspora Festival }\end{array}$ & 0.832 & & & & \\
\hline $\begin{array}{c}\text { I will tell other people positive things about the Badagry } \\
\text { Diaspora Festival. }\end{array}$ & 0.836 & & & & \\
\hline Website quality & & 0.788 & 0.889 & 0.878 & 1.979 \\
\hline I use the website of the festival & 0.851 & & & & \\
\hline The web provides quality information & 0.914 & & & & \\
\hline There is good service interaction & 0.791 & & & & \\
\hline Cultural motivation & & 0.674 & 0.841 & 0.837 & 2.309 \\
\hline The destination has quality beach & 0.778 & & & & \\
\hline There are Interesting and friendly local people & 0.799 & & & & \\
\hline I have Experience different cultures & 0.728 & & & & \\
\hline The festival destination is historic old cities & 0.711 & & & & \\
\hline
\end{tabular}

Note: average variance extracted (AVE), composite reliability (CR).

4. Results

\subsection{Descriptive Statistics}

Before proceeding to the main analysis, we examined the respondent characteristics using frequencies and simple percentages contained in Table 1 . The results indicated that although more men were captured, the sample contained a reasonable proportion of both male $(54.6 \%)$ and female $(45.4 \%)$ visitors to the festival who participated in the survey. The majority of the respondents represented (54\%) were unmarried (singles), while about $38.1 \%$ of them were married. A few of the respondents represented $(5.9 \%)$ were married but separated, while only $2 \%$ of the respondents were divorced. Similarly, some of the respondents represented (4.1\%) held a Bachelor's degree, a reasonable number of them (118) represented 28.4\% had completed high school, and 19.7\% were Master's degree graduates. Moreover, $5.7 \%$ of the respondents were Ph.D. holders, while very few of them $(5 \%)$ finished at primary school. This shows that most of the visitors who visited the Badagry Door of Return Festival were educated and enlightened. Furthermore, the majority of the respondents represented (94.7\%) were youths (between the ages 18-55 years) from different walks of life distributed across 12 different nationalities $(66.4 \%)$ who had attended the festival more than one time. This shows that the segments of the population, that actively engages in social media activities and equally attend the festivals, are well captured in the sample of respondents for this study. As such, information retrieved from them constituted the most reliable and relevant data for further analysis in this study.

\subsection{Reliability and Validity of Measurement Scales}

The assessment of the model measures are presented in Table 2. The results shows that the loadings of all the items associated with social media marketing (SM), festival satisfaction (FS), revisiting intention (RI), festival quality (FQ), eWOM, website quality (WQ), and cultural motivation (CM) were greater than the threshold value of 0.5 , in addition, the $p$-values associated with these loadings were found to be statistically significant at less than $1 \%$ confidence level. This is an indication according to Kock $[155,156]$ and Kock and 
Lynn [157] that the measurement instrument utilized for the constructs demonstrated a good "convergent validity". Moreover, the "Cronbach alpha" and "composite reliability" coefficients for SM (0.922 and 0.894), FS (0.815 and 0.852), RI (0.855 and 0.826), FQ (0.914 and 0.916), eWOM (0.914 and 0.915), WQ (0.878 and 0.889), and CM (0.837 and 0.841), respectively, as shown in Table 2, were both greater than the conservative threshold value of $0.5[155,156]$, which is an indication that the measurement instrument had a good reliability. In addition, the "average variance extracted" of SM (0.724), FS (0.570), RI (0.691), FQ (0.620), eWOM (0.797), WQ (0.788), and CM (0.674) were all greater than threshold value of $0.5[10,156]$, which is an indication of an acceptable internal consistency. Finally, the associated "full collinearity variance inflation" (FVIF) with SM (2.227), FS (2.352), RI (2.258), FQ (2.749), eWOM (1.658), WQ (1.979), and CM (2.309) were all below the recommended threshold of less than (5.0). According to Kock and Lynn [157], the coefficient of FVIF is "a model-wide measure of multi-collinearity, calculated in a way that incorporates the variations in the other variables in the model, and that allows us to test whether respondents viewed our constructs as conceptually different from all of the other constructs".

In addition to the assessment of the measurement instrument reliability, we examined the discriminant validity of the constructs. The results, as presented in Table 3, showed a conformity with the proposition in the literature that the "square root of average variance extracted shown in diagonal of each construct must be greater than the correlations between that construct and other constructs" [158]. Our result is an indication that the festival satisfaction, web quality, festival quality, social media marketing, online word of mouth, revisiting intention, and cultural motivation displayed good discriminant validity in the context of our model.

Table 3. Discriminant validity of constructs.

\begin{tabular}{|c|c|c|c|c|c|c|c|}
\hline & FS & WQ & FQ & SM & eWOM & RI & $\mathrm{CM}$ \\
\hline Festival satisfaction (FS) & 0.755 & & & & & & \\
\hline Web Quality (WQ) & $0.564^{* * *}$ & 0.888 & & & & & \\
\hline Festival Quality (FQ) & $0.661^{* * *}$ & $0.623^{* * *}$ & 0.788 & & & & \\
\hline Social Media (SM) & $0.610 * * *$ & $0.621^{* * *}$ & $0.647^{* * *}$ & 0.851 & & & \\
\hline Online word of mouth (eWOM) & $0.480 * * *$ & $0.273^{* * *}$ & $0.455^{* * *}$ & $0.367^{* * *}$ & 0.893 & & \\
\hline Revisiting Intention (RI) & $0.579^{* * *}$ & $0.501^{* * *}$ & $0.631^{* * *}$ & $0.568^{* * *}$ & $0.519^{* * *}$ & 0.831 & \\
\hline Cultural motivation (CM) & $0.553^{* * *}$ & $0.415^{* * *}$ & $0.622 * * *$ & $0.514^{* * *}$ & $0.560 * * *$ & $0.648^{* * *}$ & 0.821 \\
\hline
\end{tabular}

*** Correlation is significant at the 0.01 level (2-tailed). Bold text are square roots of average variance extract (AVE).

\subsection{Common Bias Method (CMB)}

Moreover, in respect to the "common method bias" (CMB), it was demonstrated in the study of Kock [156] that the coefficients of "full collinearity VIF" are particularly sensitive to "pathological common variations" across the constructs in methodological contexts that were the same as the one found in this study. This implies that the sensitivity enables CMB to be identified in a model, which nevertheless passes the assessment of convergent and discriminant validity criteria based on a "confirmatory factor analysis" (CFA), as we have in this study. Some studies suggested a threshold value of 5 to be acceptable and $<3.3$ to be the best for full collinearity VIF coefficients $[156,157]$. Thus, with the full VIF presented in Table 2, none of the full VIF coefficients were greater than the acceptable threshold $(\leq 5)$, which is an indication that this study measurement was free from "common bias method".

\subsection{Hypothesis Testing}

To test the structural model's quality, the model fit indices were examined and are reported in Table 4. All the indices were either statistically significant or inconsistent with the respective thresholds, indicating that the quality of our structural model was adequate $[10,154,159]$. 
Table 4. Model fit and quality indices.

\begin{tabular}{ccc}
\hline Indices & Coefficient & Decision \\
\hline Average path coefficient (APC) & 0.271 & $p<0.001$ \\
\hline Average R-squared (ARS) & 0.472 & $p<0.001$ \\
\hline Average block VIF (AVIF) & 1.717 & Supported if $\leq 5$, ideally $\leq 3.3$ \\
\hline Average full collinearity VIF (AFVIF) & 2.143 & Supported if $\leq 5$, ideally $\leq 3.3$ \\
\hline Tenenhaus GOF (GOF) & 0.588 & Small $\geq 0.1$, medium $\geq 0.25$, large $\geq 0.36$ \\
\hline R-squared contribution ration (RSCR) & 1.00 & Supported if $\geq 0.9$, ideally $=1$ \\
\hline Standardized root mean squared residual (SRMR) & 0.057 & Supported if $\leq 0.1$ \\
\hline Standardized chi-squared (SChS) & 10.772 & $p<0.001$ \\
\hline
\end{tabular}

Consequently, the structural model was estimated and the results are presented in Table 5 and Figure 2. The result of the hypothesized relationship between social media and festival satisfaction (H1) showed a positive and significant coefficient $(\beta=0.204$, $p<0.001$ ). Therefore, $\mathrm{H} 1$ was accepted and we concluded that a change in the social media awareness of the Badagry festival increased the perception of the tourists regarding festival satisfaction at less than $1 \%$ confidence level. Similarly, the parameter estimates of festival quality (FQ) $(\beta=0.326, p<0.001)$,) were positive and statistically significant at $1 \%$ level of significance. This suggests the acceptance of hypothesis two (H2), which stated that festival quality has a significant positive relationship with the tourists' festival satisfaction. Moreover, the hypothesized relationship between website quality and festival quality (H3) on one hand, and eWOM and the festival satisfaction $(\mathrm{H} 4)$ on the other hand were found to be significant. The estimates of the coefficient of web quality $(\beta=0.189, p<0.001)$, and online word of mouth (eWOM) $(\beta=0.200, p<0.001)$ were statistically significant, and thus did have a significant effect on the festival satisfaction. Therefore, both $\mathrm{H} 3$ and $\mathrm{H} 4$ were accepted and we concluded that web quality and online word of mouth do have a positive and significant influence on the tourists' perceptions of festival satisfaction at less than $1 \%$ confidence level. In addition, the direct relationship between festival satisfaction and festival revisiting intention was hypothesized in H5. The results, as presented in Table 4, showed that the coefficient was positive and significant $(\beta=0.428, p<0.001)$. Therefore, we accepted $\mathrm{H} 5$ and concluded that festival satisfaction had a significant influence on the festival revisiting intention at less than $1 \%$ confidence level. This implies that festival satisfaction is a significant driver of the tourists' intention to revisit the festival. Succinctly, the results of the SEM reveal that social media, festival quality, website quality, and online word of mouth determine the satisfaction of the tourists regarding the festival, which in turns determines their intention to revisit the festival.

Table 5. Structural hypothesis testing.

\begin{tabular}{cccccc}
\hline Hypothesis & Interaction & Estimate $(\beta)$ & S.E. & $p$-Value $(p)$ & Decision \\
\hline H1 & SM $\rightarrow$ FS & 0.204 & 0.045 & $<0.001$ & Supported \\
H2 & FQ $\rightarrow$ FS & 0.326 & 0.044 & $<0.001$ & Supported \\
H3 & WQ $\rightarrow$ FS & 0.189 & 0.045 & $<0.001$ & Supported \\
H4 & eWOM $\rightarrow$ FS & 0.200 & 0.045 & $<0.001$ & Supported \\
H5 & FS $\rightarrow$ RI & 0.428 & 0.044 & $<0.001$ & Supported \\
Age & & 0.004 & 0.022 & 0.869 & \\
Gender & & 0.047 & 0.054 & 0.385 & \\
Education level & & 0.041 & 0.029 & 0.165 & \\
Marital status & & 0.024 & 0.039 & 0.539 &
\end{tabular}

Note: SM = social media, FS = festival quality, WB = website quality, eWOM = online word of mouth, FS = festival satisfaction, RI = revisit intention. 


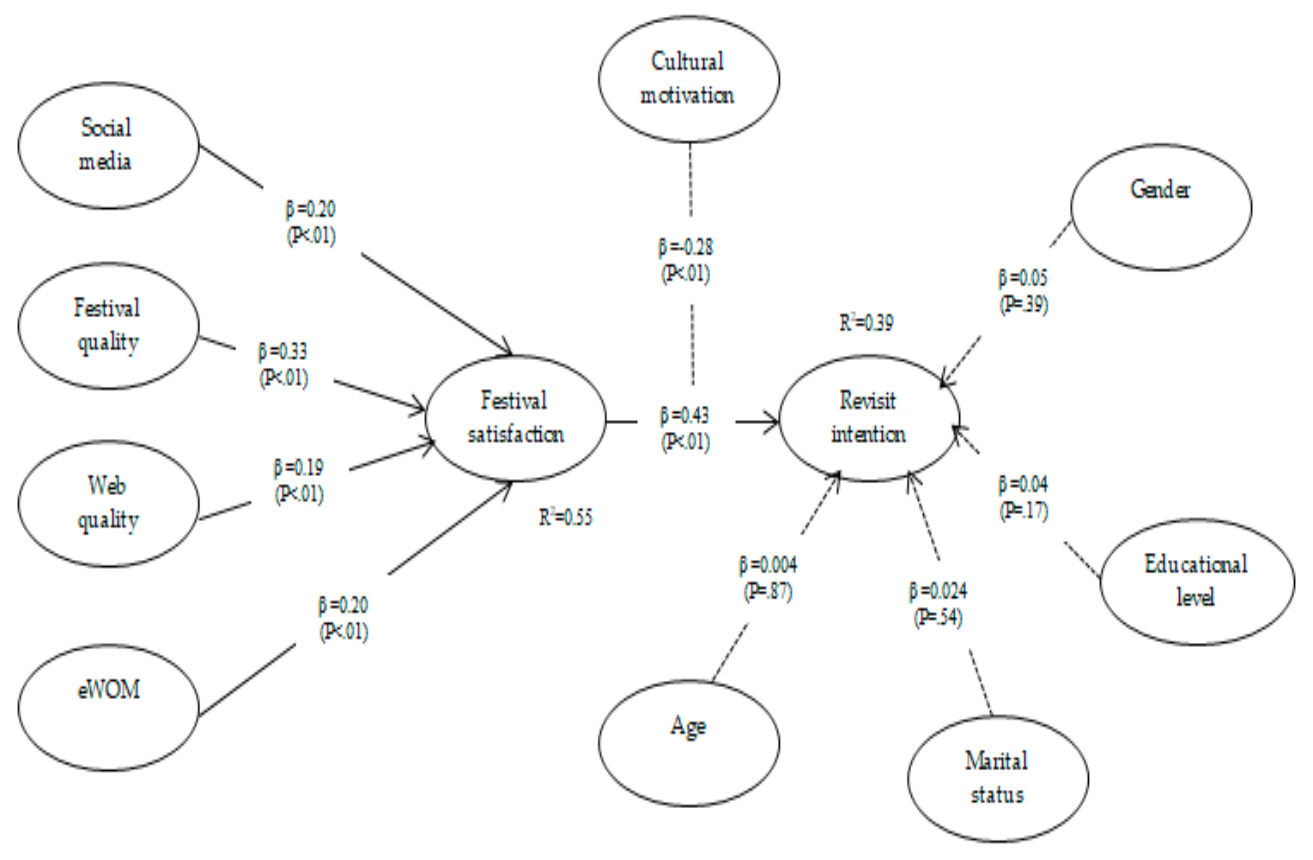

Figure 2. The Structural Equation Model Testing.

Meanwhile, the results of the SEM, as presented in Table 5, showed that all the control variables were not statistically significant. That is an indication that age, gender, education level, and marital status are not significant control variables in the relationship between the antecedents of festival satisfaction (social media, festival quality, website quality, and eWOM) of tourists' satisfaction about the Badagry Door of Return Festival and their intention to revisit. In addition, the model's results, as presented in Figure 2, showed that social media marketing, festival quality, website quality, and online word of mouth provided about $55 \%$ explanation of variation in explaining the tourists' festival satisfaction, while tourists' festival satisfaction provided about $39 \%$ explanation of variation interpreting the intention to revisit the festival tourism destination (see Figure 2).

Moreover, the mediating effects of festival satisfaction in the relationship between social media, festival quality, website quality, eWOM, and festival revisiting intention were examined and the results are presented in Table 6 . As presented in Table 6, FS partially mediated SM and RI ( $\beta=0.087, \mathrm{P}=0.003), \mathrm{FQ}$ and RI $(\beta=0.140, p<0.001)$, WQ and RI ( $\beta=0.081, P=0.006)$, eWOM and RI $(\beta=0.086, P=0.004)$, and revisit intention, which were statistically significant at less than $5 \%, 1 \%, 5 \%$, and $5 \%$ confidence levels, respectively. Therefore, we accepted H6a-d and concluded that the relationship between social media, festival quality, website quality, eWOM, and revisit intention were partially mediated by festival satisfaction. In addition, the finding from our estimation revealed that cultural motivation (CM) is a significant moderator for the relationship between festival satisfaction and revisit intention $(\beta=-0.280, p<0.001)$ at less than $1 \%$ confidence level.

Table 6. Mediation/moderation results.

\begin{tabular}{cccccc}
\hline Hypothesis & Interaction & Estimate $(\boldsymbol{\beta})$ & S.E. & $p$-Value $(p)$ & Decision \\
\hline H6a & $\mathrm{SM} \rightarrow \mathrm{FS} \rightarrow$ RI & 0.087 & 0.032 & 0.003 & Supported \\
H6b & FQ $\rightarrow$ FS $\rightarrow$ RI & 0.140 & 0.032 & $<0.001$ & Supported \\
H6c & WQ $\rightarrow$ FS $\rightarrow$ RI & 0.081 & 0.032 & 0.006 & Supported \\
H6d & eWOM $\rightarrow$ FS $\rightarrow$ RI & 0.086 & 0.032 & 0.004 & Supported \\
H7 & CM $*$ FS & -0.280 & 0.044 & $<0.001$ & Supported \\
\hline
\end{tabular}

Note: $\mathrm{SM}=$ social media, FS = festival quality, $\mathrm{WB}=$ website quality, eWOM = online word of mouth, FS = festival satisfaction, $\mathrm{RI}=$ revisit intention, $\mathrm{CM}=$ cultural motivation. 


\section{Discussion of Findings}

Social media (SM) serves as an indispensable means for the promoting the diaspora festival as a cultural tourism destination [14]. Thus, we examined the relationship between social media and the tourists' intention to revisit Badagry Diaspora Festival. This study provides empirical insights on how social media is used as a destination marketing tool to promote the Badagry Diaspora Festival in Nigeria.

We used partial least square structural equation modeling (PLS-SEM) to examine the nexus between social media (SM), website quality (WQ), online word of mouth (eWOM) tourists' festival satisfaction (FS), and festival revisiting intention. The control variables included in the models, age, gender, education background, nationality, and marital status, did not have crucial impacts on the relationships of the variables in the study. The findings revealed that social media (SM), website quality (WQ), and online word of mouth (eWOM) had a positive and significant relationship with online tourists' festival satisfaction (FS). Moreover, this study found that festival quality had a positive and significant effect on the intention of the tourists to revisit the Badagry Diaspora Festival. Furthermore, we found that festival satisfaction partially mediated the positive relationship between the antecedents of festival satisfaction (SM, FQ, WQ, and eWOM) and festival revisiting intension.

It should be noted also that website quality (WQ) and electronic word of mouth (eWOM) were essentially designed to promote festival satisfaction, which in turn promoted the intention to revisit the Badagry Diaspora Festival. So therefore, the use of the social media sites by the customers creates various marketing innovations, which enables the generation of online content and sharing of information about cultural tourism products and services. The social media marketing provides the platforms for the DMOs (government of Nigeria) to interact with the tourists who can promote the Badagry festival destination. This corroborates the findings of Osei et al., [3] and Navío-Marco et al. [4], who found that social media marketing presents opportunities, through numerous networking sites including Facebook, Twitter, and YouTube, for the creation of online content and advertising tourism product and services.

In addition, $\mathrm{H} 3$, which measured the relationship between website quality and tourist satisfaction, as well as the influence of electronic word of mouth (e-WOM) on festival satisfaction (H4), were both statistically significant. This implies that the Door of Return Festival planners must recognize how to influence the use of social media marketing as it relates to website quality and eWOM so as to boost the festival quality. The findings are consistent with Lund et al., [7] who established that the relationship between social media marketing and e-word of mouth are the most powerful determinants of diaspora festival satisfaction. The findings are also in consonance with the conclusions of Dedeoğlu et al., [66], who reported that the Internet and social media are the two most significant communication networks shaping the festival brand awareness to tourists. DMOs must develop suitable interaction with actual and potential tourists in order to ascertain the niche markets required to promote festival destinations.

Moreover, this study revealed the significant moderating role of cultural motivation in the relationship between festival satisfaction and festival revisiting intention. Hence, a growing body of knowledge recognizes that tourist behavior is influenced by the sociocultural background of tourists [149]. It is presumed that African-Americans, by virtue of their cultural ties with Africa, may desire to visit the land of their ancestors. The intention to revisit the Badagry festival is boosted by the general interest of the tourist in exploring their culture, history, and the numerous heritage sites found in the Badagry festival destination. The cultural motivation, derivable from the cultural affinity African-Americans have with Africa, enhances the festival satisfaction and propels the intention to revisit the festival destination. This is in line with the submission Liu et al. [146] and HernándezMogollón et al., [147], who revealed that the success of tourism destination marketing is affected by tourist satisfaction and its relationship with tourists' revisiting intentions is largely dependent upon the tourists' cultural motivation. 


\subsection{Conclusions}

This study examined how social media as a destination marketing tool is used to promote Badagry Diaspora Festival, drawing on the theory of planned behavior (TPB). The partial least square structural equation modeling (PLS-SEM) method was used. The study evaluated the causal relationship between social media, festival quality, website quality, e-WOM, and the mediating of tourist satisfaction and revisiting intention, as well as the moderating role of cultural motivation in the tourists' intention to revisit the festival. The study provides evidence that social media, festival quality, and eWOM are significant antecedents for tourists' perceived festival satisfaction of the Badagry Diaspora Festival in Nigeria. Festival satisfaction was revealed to be a significant antecedent for tourists' intention to revisit. In addition, festival satisfaction and cultural motivation were found to significantly mediate and moderate, respectively, the relationship between perceived tourists' revisit intention and its antecedents in attracting tourists to revisit the Badagry Diaspora Festival. It is therefore imperative to state that the success of tourism destinations in marketing the cultural heritage festival in Nigeria is basically dependent on the success of the festival event, which has created remarkable brand awareness.

The emergence of social media in promoting tourism destinations has been a rising research topic. Tourism has witnessed the promotion of various segments, especially in decision making and searching for information, promoting tourism publicity by focusing specifically on interacting with the consumer as the best practice. Leveraging off social media marketing for Badagry Diaspora Festival has proven to be an outstanding strategy for festival promotion. This paper suggests that an investigation on social media and destination marketing is still in its infancy stage in Nigeria. It is crucial to encourage wide-ranging exploration into the influence and impact of social media, which will serve as part of tourism management and a strategic marketing system as it relates to the entire tourism industry, including local festival destinations, in order to demonstrate the economic contributions of social media to the tourism and hospitality industry. Social media is no doubt a significant tool in marketing in developed countries like the UK and the USA [21], as well as for developing countries [67], which was also validated in this study for the Badagry Diaspora Festival in Lagos state.

\subsection{Managerial Implications of the Study}

This study contributes to the empirical justification of the theory of planned behavior because the findings revealed that the tourists' intentions to revisit the Diaspora Festival are determined by festival satisfaction and cultural motivation, which are promoted by social media sites. Based from the evidence of this study, the TPB assumptions have been validated, which suggests that consumer behavior to revisit holds when some factors stimulate their individual behavior. In the case of this study, website quality social media, eWOM, and festival quality were proposed as antecedents to behavioral intentions, as well as using festival satisfaction as a mediating variable. This is with the view that the antecedent variables could possibly not have an indirect influence on the intention to revisit the festival. In addition, the TPB was extended to accommodate a moderating variable (cultural motivation). The significance of this variable demonstrates that in understanding the intention of tourists to revisit the Diaspora Festival, cultural motivation plays a significant moderating role. Hence, the tourist's decision is based on careful judgment of the content of the festival (planned behavior).

In addition, this study suggested some valuable managerial implications. First, the study provides an empirical insight into consumer responses on valuable information to the planners, organizers, and exhibitors of the Badagry Diaspora Festival to design and provide quality festival products. The Lagos state Ministry of Tourism and the Nigerian government should modify and create an active website for tourism pages/accounts on major social media sites that can be constantly used as social media links to interact and engage with the African diaspora, and it can be tagged as "event announcement media", which can be shared across all media channels. Social media platforms, such as Twitter, 
LinkedIn, Facebook, and WhatsApp, should be frequently updated by qualified digital personnel who can respond to questions and complaints that can generate and maintain manage good image of the Badagry Diaspora Festival on social media platforms. Based on this, the social media platforms can serve as a good connection to tourists/medium for content analysis in the nearer future.

Secondly, the study uncovered the viability of the social media in creating the platforms, which can help promote tourists revisiting intensions of the festival. Currently, based on our observation, the DMOs marketing the diaspora festival event in Badagry Nigeria do not extensively recognize social media as a vital marketing tool for the festival. DMOs are however still complimenting the social media tools with other traditional way of marketing due to underfunding/neglect of the tourism sector. We advise that the DMOs should optimize the use of different kinds of options (blogs, website publicity, emails, websites) and social media sites to reach out to former festival attendees and keep them informed, and communicate with all service providers, such as travel agents, hoteliers and transport service providers, in order to boost the cultural heritage festival.

Thirdly, this study revealed the destination marketing strategies that will support the DMOs to implement innovative and suitable approaches for promoting the festival. The major strategy is to enhance the quality of the website and focus on the use of the social networking sites to market the festival. Quality local cultural heritage products from festival destinations, such as historic places, local foods, and hotel accommodation, should be packaged and advertised via the social media by the DMOs in order to improve their social media marketing activities in enhancing the festival quality. Additionally, the DMOs who are vested with the responsibility of the festival should focus on providing a festival program and activities that festival attendees admire by including thematic contents such "diaspora festival the black beauty nation" and "African legacy with cultural performances" to ensure superiority inspiration among festival attendees. This is essential because the findings of the study revealed the importance of cultural motivation in shaping the nexus between festival satisfaction and revisiting intention of the tourists.

Fourthly, DMOs should further employ the services of social media experts who understand social media tools and internet statistics to keep track of records on social media and festival events in order to disclose important key information about Badagry Diaspora Festival to tourist information centers in order to help generate a database for the festival revisiting intentions.

Fifthly, a periodic report should be sent to the National Tourism Board on the trends of social media and destination marketing as this will assist researchers and marketing managers strategize on how to make the Diaspora Festival a very pleasurable and memorable festival satisfaction to all festival attendees.

Sixthly, DMOs should try and implement good festival incentives that can give diaspora tourists affordable meals by using coupons that can serve as discount tickets on hotel accommodations, lodging houses, or eateries. The world is technologically driven, the use of ATM cards and cash paying machines should be reinforced in all local markets to enhance the festival by making it a cashless tourism destination that will be free from insecurity and hooligans.

Finally, the Lagos State Ministry of Tourism should ensure that the progress of Badagry Diaspora Festival is properly managed to ensure that the festival records are kept straight in measuring the festival development in terms of technological advancement so that the potential and existing diaspora tourist interest is sustained and preserved.

\subsection{Limitation and Direction for Future Studies}

Research on the linkage between social media as a marketing tool and the tourism and hospitality industry is diverse and requires multidisciplinary collaboration, which was not done in this study. So, for detailed analysis of the issues, future researchers should engage experts from different research areas, including tourism and hospitality management, information technology, marketing management, festival planners, tourism 
economist, behavioral science, and other related disciplines. In this way, the essential factors for the development of effective predictive models of tourism marketing in a social media environment can be enhanced. In addition, it will be interesting to investigate the mediating role of "wildcard events" (tourism crisis) in the model and the moderating role of the effect of "individual cultural values" concerning social media experiences with tourism destinations. Specifically, food and beverage quality and staff behavior have been identified as the two crucial attributes that can shape the attitudes of festival attendees. Thus, it may be beneficial to investigate these two characteristics individually and extensively in order to comprehend more clearly the specific features that influence the attitudes and revisiting intentions of the diaspora festival attendees. Nevertheless, it is evident from the study findings that the cultural heritage festival, which is otherwise known as the Badagry Diaspora Festival (The Door of Return Festival) in Lagos has the capacity to become sustainable if the DMOs and festival planners can use the findings from this study as a guide. Moreover, in as much as the tourists are satisfied with the festival, the intention to revisit will be encouraged and this will translate to the sustainability of the festival.

Author Contributions: H.A. completed the introduction and theoretical background sections. M.A. wrote the methodology and results sections. T.G. contributed to reviewing the recent literature. All authors wrote the discussion and results parts and checked the latest version of the paper. All authors have read and agreed to the published version of the manuscript.

Funding: This research received no external funding.

Institutional Review Board Statement: Not applicable.

Informed Consent Statement: Not applicable.

Data Availability Statement: The data presented in this study are available on request from the corresponding author.

Conflicts of Interest: The authors declare no conflict of interest.

\section{References}

1. Appel, G.; Grewal, L.; Hadi, R.; Stephen, A.T. The future of social media in marketing. J. Acad. Mark. Sci. 2020, 48, 79-95. [CrossRef]

2. Alizadeh, A.; Isa, R.M. The use of social media in destination marketing: An exploratory study. Tour. Int. Interdiscip. J. 2015, 63, 175-192.

3. Osei, B.A.; Mensah, I.; Amenumey, E.K. Utilisation of social media by international tourists to Ghana. Anatolia 2018, 29, 411-421. [CrossRef]

4. Navío-Marco, J.; Ruiz-Gómez, L.M.; Sevilla-Sevilla, C. Progress in information technology and tourism management: 30 years on and 20 years after the internet-Revisiting Buhalis \& Law's landmark study about eTourism. Tour. Manag. 2018, 69, 460-470.

5. Mariani, M.M.; Di Felice, M.; Mura, M. Facebook as a destination marketing tool: Evidence from Italian regional Destination Management Organizations. Tour. Manag. 2016, 54, 321-343. [CrossRef]

6. Andrlić, B.; De Alwis, A.C. Social media in destination marketing. Int. J. Manag. Appl. Sci. 2016, 2, 121-125.

7. Lund, N.F.; Cohen, S.A.; Scarles, C. The power of social media storytelling in destination branding. J. Destin. Mark. Manag. 2018, 8, 271-280. [CrossRef]

8. Cheng, J.C.H.; Chiang, A.H.; Yuan, Y.; Huang, M.Y. Exploring antecedents of green tourism behaviors: A case study in suburban areas of Taipei, Taiwan. Sustainability 2018, 10, 1928. [CrossRef]

9. Niñerola, A.; Sánchez-Rebull, M.V.; Hernández-Lara, A.B. Tourism research on sustainability: A bibliometric analysis. Sustainability 2019, 11, 1377. [CrossRef]

10. Cheunkamon, E.; Jomnonkwao, S.; Ratanavaraha, V. Determinant Factors Influencing Thai Tourists' Intentions to Use Social Media for Travel Planning. Sustainability 2020, 12, 7252. [CrossRef]

11. Casaló, L.V.; Romero, J. Social media promotions and travelers' value-creating behaviors: The role of perceived support. Int. J. Contemp. Hosp. Manag. 2019, 31, 633-650. [CrossRef]

12. Királ'ová, A.; Pavlíčeka, A. Development of social media strategies in tourism destination. Procedia Soc. Behav. Sci. 2015, 175, 358-366. [CrossRef]

13. Pino, G.; Peluso, A.M.; Del Vecchio, P.; Ndou, V.; Passiante, G.; Guido, G. A methodological framework to assess social media strategies of event and destination management organizations. J. Hosp. Mark. Manag. 2019, 28, 189-216. [CrossRef]

14. Bravo, V. Engaging the Diaspora: El Salvador and Costa Rica's Use of Social Media to Connect with Their Diaspora Communities in the United States. Glob. Media J. 2012, 11, 7521. 
15. Uddin, Z.; Krohn, F.B. Marketing Africa as a tourist destination in the United States: Nigeria, a case in point. Tour. Rev. 1990, 45, 7-11. [CrossRef]

16. Morrison, A.M. Marketing and Managing Tourism Destinations, 2nd ed.; Routledge: Oxon, UK; New York, NY, USA, 2019.

17. Hudson, S.; Hudson, R. Engaging with consumers using social media: A case study of music festivals. Int. J. Event Festiv. Manag. 2013, 4, 206-223. [CrossRef]

18. Hays, S.; Page, S.J.; Buhalis, D. Social media as a destination marketing tool: Its use by national tourism organizations. Curr. Issues Tour. 2013, 16, 211-239. [CrossRef]

19. Felix, R.; Rauschnabel, P.A.; Hinsch, C. Elements of strategic social media marketing: A holistic framework. J. Bus. Res. 2017, 70, 118-126. [CrossRef]

20. Harrigan, P.; Evers, U.; Miles, M.; Daly, T. Customer engagement with tourism social media brands. Tour. Manag. 2017, 59, 597-609. [CrossRef]

21. Zeng, B.; Gerritsen, R. What do we know about Social Media in Tourism? A review. Tour. Manag. Perspect. 2014, 10, 27-36. [CrossRef]

22. Hudson, S.; Roth, M.S.; Madden, T.J.; Hudson, R. The effects of social media on emotions, brand relationship quality, and word of mouth: An empirical study of music festival attendees. Tour. Manag. 2015, 47, 68-76. [CrossRef]

23. Prayag, G.; Hosany, S.; Muskat, B.; Del Chiappa, G. Understanding the relationships between tourists' emotional experiences, perceived overall image, satisfaction, and intention to recommend. J. Travel Res. 2017, 56, 41-54. [CrossRef]

24. Shen, S.; Sotiriadis, M.; Zhou, Q. Could smart tourists be sustainable and responsible as well? The contribution of social networking sites to improving their sustainable and responsible behavior. Sustainability 2020, 12, 1470. [CrossRef]

25. Getz, D. Event tourism: Definition, evolution, and research. Tour. Manag. 2008, 29, 403-428. [CrossRef]

26. Brubaker, R. The 'diaspora' diaspora. Ethn. Racial Stud. 2005, 28, 1-19. [CrossRef]

27. Lovejoy, P.E. The Impact of the Atlantic Slave Trade on Africa: A Review of the Literature. J. Afr. Hist. 1989, 30, 368. [CrossRef]

28. UNESCO. Education for Sustainable Development Goals: Learning Objectives; UNESCO: Paris, France, 2017.

29. Ndletyana, M. African intellectuals in 19th and Early 20th Century South Africa. HSRC 2008.

30. Alcántara-Pilar, J.M.; Armenski, T.; Blanco-Encomienda, F.J.; Del Barrio-García, S. Effects of cultural difference on users' online experience with a destination website: A structural equation modelling approach. J. Destin. Mark. Manag. 2018, 8, 301-311. [CrossRef]

31. Chang, M.; Kim, J.H.; Kim, D. The effect of food tourism behavior on food festival visitor's revisit intention. Sustainability 2018, 10, 3534. [CrossRef]

32. Ajzen, I. The theory of planned behavior. Organ. Behav. Hum. Decis. Process. 1991, 50, 179-211. [CrossRef]

33. Ajzen, I. Residual effects of past on later behavior: Habituation and reasoned action perspectives. Personal. Soc. Psychol. Rev. 2002, 6, 107-122. [CrossRef]

34. Yamada, N.; Fu, Y.Y. Using the theory of planned behavior to identify beliefs underlying visiting the Indiana State Museum. J. Travel Tour. Mark. 2012, 29, 119-132. [CrossRef]

35. Shen, S. Intention to revisit traditional folk events: A case study of Qinhuai Lantern Festival, China. Int. J. Tour. Res. 2014, 16, 513-520. [CrossRef]

36. Baker, D.A.; Crompton, J.L. Quality, satisfaction, and behavioral intentions. Ann. Tour. Res. 2000, 27, 785-804. [CrossRef]

37. Lee, S.; Jeon, S.; Kim, D. The impact of tour quality and tourist satisfaction on tourist loyalty: The case of Chinese tourists in Korea. Tour. Manag. 2011, 32, 1115-1124. [CrossRef]

38. Oppermann, M. First-Time and Repeat Visitors to New Zealand. Tour. Manag. 1997, 18, 177-181. [CrossRef]

39. Rittichainuwat, B.; Mair, J. Visitor attendance motivations at consumer travel exhibitions. Tour. Manag. 2012, 33, 1236-1244. [CrossRef]

40. Vesci, M.; Botti, A. Festival quality, theory of planned behavior and revisiting intention: Evidence from local and small Italian culinary festivals. J. Hosp. Tour. Manag. 2019, 38, 5-15. [CrossRef]

41. Mason, M.C.; Paggiaro, A. Investigating the role of festival scape in culinary tourism: The case of food and wine events. Tour. Manag. 2012, 33, 1329-1336. [CrossRef]

42. Choo, H.; Ahn, K.; Petrick, J.F. An integrated model of festival revisit intentions: Theory of planned behavior and festival quality/satisfaction. Int. J. Contemp. Hosp. Manag. 2016, 28, 818-838. [CrossRef]

43. World Tourism Organization. UNWTO Tourism Highlights; World Tourism Organization: Madrid, Spain, 2016.

44. World Tourism Organization. Tourism Towards 2030/Global Overview; World Tourism Organization: Madrid, Spain, 2011.

45. World Tourism Organization. UNWTO Annual Report 2015, UNWTO; World Tourism Organization: Madrid, Spain, 2016.

46. Gössling, S.; Scott, D.; Hall, C.M. Pandemics, tourism and global change: A rapid assessment of COVID-19. J. Sustain. Tour. 2020, 29, 1-20. [CrossRef]

47. Christie, I.; Fernandes, E.; Messerli, H.; Twining-Ward, L. Tourism in Africa: Harnessing Tourism for Growth and Improved Livelihoods; The World Bank: Washington, DC, USA, 2013.

48. Ibrahim, A.N.H.; Borhan, M.N.; Rahmat, R.A.O. Understanding users' intention to use park-and-ride facilities in Malaysia: The role of trust as a novel construct in the theory of planned behaviour. Sustainability 2020, 12, 2484. [CrossRef]

49. Kirillova, K.; Lehto, X.Y.; Cai, L. Existential authenticity and anxiety as outcomes: The tourist in the experience economy. Int. J. Tour. Res. 2017, 19, 13-26. [CrossRef] 
50. Foris, D.; Florescu, A.; Foris, T.; Barabas, S. Improving the Management of Tourist Destinations: A New Approach to Strategic Management at the DMO Level by Integrating Lean Techniques. Sustainability 2020, 12, 10201. [CrossRef]

51. Kotoua, S.; Ilkan, M.; Abdullahi, M. Destination Marketing and Tourism Entrepreneurship in Ghana. In Emerging Trends in Banking and Finance; Springer: Cham, Switzerland, 2018; pp. 155-180.

52. Peppard, J.; Ward, J. The Strategic Management of Information Systems: Building a Digital Strategy; John Wiley \& Sons: Hoboken, NJ, USA, 2016.

53. Wise, N.; Flinn, J.; Mulec, I. Exit Festival: Contesting political pasts, impacts on youth culture and regenerating the image of Serbia and Novi Sad. Ideol. Soc. Cult. Asp. Events 2015, 3526, 60-73.

54. Lee, C.; Shin, J.; Hong, A. Does social media use really make people politically polarized? Direct and indirect effects of social media use on political polarization in South Korea. Telemat. Inform. 2018, 35, 245-254. [CrossRef]

55. Luciana Chavez, L.; Ruiz, C.; Curras, R.; Blanca Hernandez, B. The Role of Travel Motivations and Social Media Use in Consumer Interactive Behaviour: A Uses and Gratifications Perspective. Sustainability 2020, 12, 8789. [CrossRef]

56. Grappi, S.; Montanari, F. The role of social identification and hedonism in affecting tourist re-patronizing behaviors': The case of an Italian festival. Tour. Manag. 2011, 32, 1128-1140. [CrossRef]

57. Rim, H.; Lee, Y.; Yoo, S. Polarized public opinion responding to corporate social advocacy: Social network analysis of boycotters and advocators. Public Relat. Rev. 2020, 46, 101869. [CrossRef]

58. Wattanacharoensil, W.; Schuckert, M. How global airports engage social media users: A study of Facebook use and its role in stakeholder communication. J. Travel Tour. Mark. 2015, 32, 656-676. [CrossRef]

59. Xiang, Z.; Gretzel, U. Role of Social Media in Online Travel Information Search. Tour. Manag. 2010, 31, 179-188. [CrossRef]

60. Alghizzawi, M.; Salloum, S.A.; Habes, M. The role of social media in tourism marketing in Jordan. Int. J. Inf. Technol. Lang. Stud. 2018, 2, 59-70.

61. Alzua, A.; O'Leary, J.T.; Morrison, A.M. Cultural and heritage tourism: Identifying niches for international travellers. J. Tour. Stud. 1998, 9, 2-13.

62. Cai, Z.; Huang, Q.; Liu, H.; Wang, X. Improving the agility of employees through enterprise social media: The mediating role of psychological conditions. Int. J. Inf. Manag. 2018, 38, 52-63. [CrossRef]

63. Lee, G.; Morrison, A.M.; O'Leary, J.T. The economic value portfolio matrix: A target market selection tool for destination marketing organizations. Tour. Manag. 2006, 27, 576-588. [CrossRef]

64. Chung, J.Y.; Choi, Y.K.; Yoo, B.K.; Kim, S.H. Bleisure tourism experience chain: Implications for destination marketing. Asia Pac. J. Tour. Res. 2020, 25, 300-310. [CrossRef]

65. Odigbo, B.; Ogbu, S.U.; Alfred, U.J. Assessment of the Internet as Tool for Tourism Marketing in Nigeria. Br. J. Mark. Stud. 2015, 4, 36-46.

66. Dedeoğlu, B.B.; Taheri, B.; Okumus, F.; Gannon, M. Understanding the importance that consumers attach to social media sharing (ISMS): Scale development and validation. Tour. Manag. 2020, 76, 103954. [CrossRef]

67. Jiménez-Barreto, J.; Campo-Martínez, S. Destination website quality, users' attitudes and the willingness to participate in online co-creation experiences. Eur. J. Manag. Bus. Econ. 2018, 27, 26-41. [CrossRef]

68. Kumar, P.; Mishra, J.M.; Rao, Y.V. Analysing tourism destination promotion through Facebook by Destination Marketing Organizations of India. Curr. Issues Tour. 2021, 1-16. [CrossRef]

69. Gil-Or, O. Building consumer demand by using viral marketing tactics within an online social network. Adv. Manag. 2010, 3, 7-14.

70. Wollan, R.; Smith, N.; Zhou, C. The Social Media Management Handbook: Everything You Need to Know to Get Social Media Working in Your Business; John Wiley \& Sons: Hoboken, NJ, USA, 2011.

71. eMarketer. Online Leisure Travel: Six Post-Recession Trends. 2010. Available online: http:/ /www.emarketer.com/Report.aspx? code=emarketer_2000638 (accessed on 20 January 2021).

72. Ngai, E.W.; Tao, S.S.; Moon, K.K. Social media research: Theories, constructs, and conceptual frameworks. Int. J. Inf. Manag. 2015, 35, 33-44. [CrossRef]

73. Leiper, N. Are destinations 'the heart of tourism'? The advantages of an alternative description. Curr. Issues Tour. 2000, 3, 364-368. [CrossRef]

74. Hwang, H.; Kim, K.O. Social media as a tool for social movements: The effect of social media use and social capital on intention to participate in social movements. Int. J. Consum. Stud. 2015, 39, 478-488. [CrossRef]

75. Culha, $\mathrm{O}$. The effect of food festival quality on place attachment and destination recommendation intention through festival experience and festival satisfaction: The case of the Didim International Olive Festival. J. Conv. Event Tour. 2020, 1-30. [CrossRef]

76. Gretzel, U.; Fesenmaier, D.R.; Formica, S.; O'Leary, J.T. Searching for the future: Challenges faced by destination marketing organizations. J. Travel Res. 2006, 45, 116-126. [CrossRef]

77. Song, H.; You, G.J.; Reisinger, Y.; Lee, C.K.; Lee, S.K. Behavioral intention of visitors to an Oriental medicine festival: An extended model of goal directed behavior. Tour. Manag. 2014, 42, 101-113. [CrossRef]

78. Wu, H.-C.; Wong, J.W.-C.; Cheng, C.-C. An empirical study of behavioral intentions in the food festival: The case of Macau. Asia Pacific J. Tour. Res. 2014, 19, 1278-1305. [CrossRef]

79. Choi, Y.K.; Seo, Y.; Yoon, S. E-WOM messaging on social media: Social ties, temporal distance, and message concreteness. Internet Res. 2017, 27, 495-505. [CrossRef] 
80. Silius, K.; Kailanto, M.; Tervakari, A.M. Evaluating the quality of social media in an educational context. In Proceedings of the 2011 IEEE Global Engineering Education Conference (EDUCON), Amman, Jordan, 4-6 April 2011; pp. 505-510. [CrossRef]

81. Crompton, J.L.; Love, L.L. The predictive validity of alternative approaches to evaluating quality of a festival. J. Travel Res. 1995, 34, 11-24. [CrossRef]

82. Otoo, F.E.; Kim, S.S.; King, B. African diaspora tourism-How motivations shape experiences. J. Destin. Mark. Manag. $2021,20,100565$.

83. Akhoondnejad, A. Tourist loyalty to a local cultural event: The case of Turkmen handicrafts festival. Tour. Manag. 2016, 52, 468-477. [CrossRef]

84. Lee, J. Visitors' emotional responses to the festival environment. J. Travel Tour. Mark. 2014, 31, 114-131. [CrossRef]

85. Wong, J.; Wu, H.-C.; Cheng, C.-C. An empirical analysis of synthesizing the effects of festival quality, emotion, festival image and festival satisfaction on festival loyalty: A case study of Macau food festival. Int. J. Tour. Res. 2015, 17, 521-536. [CrossRef]

86. Saleh, F.; Ryan, C. Jazz and knitwear: Factors that attract tourists to festivals. Tour. Manag. 1993, 14, 289-297. [CrossRef]

87. Cole, S.T.; Illum, S.F. Examining the mediating role of festival visitors' satisfaction in the relationship between service quality and behavioral intentions. J. Vacat. Mark. 2006, 12, 160-173. [CrossRef]

88. Azucar, D.; Marengo, D.; Settanni, M. Predicting the Big 5 personality traits from digital footprints on social media: A metaanalysis. Personal. Individ. Differ. 2018, 124, 150-159. [CrossRef]

89. Park, Y.A.; Gretzel, U.; Sirakaya-Turk, E. Measuring web site quality for online travel agencies. J. Travel Tour. Mark. 2007, 23, 15-30. [CrossRef]

90. Vinyals-Mirabent, S. European urban destinations' attractors at the frontier between competitiveness and a unique destination image. A benchmark study of communication practices. J. Destin. Mark. Manag. 2019, 12, 37-45. [CrossRef]

91. Pranić, L.; Praničević, D.G.; Arnerić, J. Hotel website performance: Evidence from a transition country. Tour. Hosp. Manag. 2014, 20, 45-60. [CrossRef]

92. Sivarajah, U.; Irani, Z.; Gupta, S.; Mahroof, K. Role of big data and social media analytics for business to business sustainability: A participatory web context. Ind. Mark. Manag. 2020, 86, 163-179. [CrossRef]

93. Ahmad, A.; Khan, M.N. Developing a website service quality scale: A confirmatory factor analytic approach. J. Internet Commer. 2017, 16, 104-126. [CrossRef]

94. Kim, H.; Fesenmaier, D.R. Persuasive design of destination web sites: An analysis of first impression. J. Travel Res. 2008, 47, 3-13. [CrossRef]

95. Parasuraman, A.; Grewal, D. The impact of technology on the quality-value-loyalty chain: A research agenda. J. Acad. Mark. Sci. 2000, 28, 168-174. [CrossRef]

96. Yekini, N.A.; Adetoba, B.A.; Edwin, E.; Oluwafemi, O. Web-based Expert Decision Support System for Tourism Destination Management in Nigeria. (IJARAI) Int. J. Adv. Res. Artif. Intell. 2013, 2, 59-63.

97. Choi, S.; Lehto, X.Y.; Morrison, A.M. Destination image representation on the web: Content analysis of Macau travel related websites. Tour. Manag. 2007, 28, 118-129. [CrossRef]

98. Fernández-Cavia, J.; Rovira, C.; Díaz-Luque, P.; Cavaller, V. Web Quality Index (WQI) for official tourist destination websites. Proposal for an assessment system. Tour. Manag. Perspect. 2014, 9, 5-13. [CrossRef]

99. Lee, W.; Gretzel, U. Designing persuasive destination websites: A mental imagery processing perspective. Tour. Manag. 2012, 33, 1270-1280. [CrossRef]

100. Volo, S. Bloggers' reported tourist experiences: Their utility as a tourism data source and their effect on prospective tourists. J. Vacat. Mark. 2010, 16, 297-311. [CrossRef]

101. Gretzel, U.; Yoo, K.H. Use and impact of online travel reviews. Inf. Commun. Technol. Tour. 2008, 2008, 35-46.

102. Dioko, L.; Harrill, R.; Munar, A.M. Tourist-created content: Rethinking destination branding. Int. J. Cult. Tour. Hosp. Res. 2011, 5, 291-305.

103. Oliveira, E.; Panyik, E. Content, context and co-creation: Digital challenges in destination branding with references to Portugal as a tourist destination. J. Vacat. Mark. 2015, 21, 53-74. [CrossRef]

104. Chaubey, D.S.; Sharma, L.S.; Pant, M. Measuring the effectiveness of online advertisement in recalling a product: An empirical study. Manag. Converg. 2015, 4, 37-47.

105. Amuquandoh, F.E. Residents' perceptions of the environmental impacts of tourism in the Lake Bosomtwe Basin, Ghana. J. Sustain. Tour. 2010, 18, 223-238. [CrossRef]

106. Cantallops, A.S.; Salvi, F. New consumer behavior: A review of research on eWOM and hotels. Int. J. Hosp. Manag. 2014, 36, 41-51. [CrossRef]

107. Mmutle, T.; Shonhe, L. Customers' perception of service quality and its impact on reputation in the hospitality industry. Afr. J. Hosp. Tour. Leis. 2017, 6, 2223-814X.

108. Wang, Y.; Pizam, A. (Eds.) Destination Marketing and Management: Theories and Applications; CABI: Nairobi, Kenya, 2011.

109. Kirilenko, A.P.; Stepchenkova, S.O.; Kim, H.; Li, X. Automated sentiment analysis in tourism: Comparison of approaches. J. Travel Res. 2018, 57, 1012-1025. [CrossRef]

110. Novais, M.A.; Ruhanen, L.; Arcodia, C. Destination competitiveness: A phenomenographic study. Tour. Manag. 2018, 64, 324-334. [CrossRef]

111. Novais, M.A.; Ruhanen, L.; Arcodia, C. Destination competitiveness: What we know, what we know but shouldn't and what we don't know but should. Current 2015, 19, 1-21. 
112. Kang, M.; Schuett, M.A. Determinants of sharing travel experiences in social media. J. Travel Tour. Mark. 2013, 30, 93-107. [CrossRef]

113. Gretzel, U.; Zhong, L.; Koo, C.; Doosti, S.; Jalilvand, M.R.; Asadi, A.; Adl, P.M. Analyzing the influence of electronic word of mouth on visit intention: The mediating role of tourists' attitude and city image. Int. J. Tour. Cities 2016, 2, 137-148.

114. Sotiriadis, M.D.; Van Zyl, C. Electronic word-of-mouth and online reviews in tourism services: The use of twitter by tourists. Electron. Commer. Res. 2013, 13, 103-124. [CrossRef]

115. Chen, Y.F.; Law, R. A review of research on electronic word-of-mouth in hospitality and tourism management. Int. J. Hosp. Tour. Adm. 2016, 17, 347-372. [CrossRef]

116. Litvin, S.W.; Goldsmith, R.E.; Pan, B. A retrospective view of electronic word-of-mouth in hospitality and tourism management. Int. J. Contemp. Hosp. Manag. 2018, 30, 313-325. [CrossRef]

117. Xu, F.; Niu, W.; Li, S.; Bai, Y. The Mechanism of Word-of-Mouth for Tourist Destinations in Crisis. SAGE 2020, 10, 1-14. [CrossRef]

118. Marchand, A.; Hennig-Thurau, T.; Wiertz, C. Not all digital word of mouth is created equal: Understanding the respective impact of consumer reviews and microblogs on new product success. Int. J. Res. Mark. 2017, 34, 336-354. [CrossRef]

119. Chu, S.C.; Kim, Y. Determinants of consumer engagement in electronic word-of-mouth (eWOM) in social networking sites. Int. J. Advert. 2011, 30, 47-75. [CrossRef]

120. Blazevic, V.; Hammedi, W.; Garnefeld, I.; Rust, R.T.; Keiningham, T.; Andreassen, T.W.; Donthu, N.; Carl, W. Beyond traditional word-of-mouth: An expanded model of customer-driven influence. J. Serv. Manag. 2013, 24, 294-313. [CrossRef]

121. Brown, J.; Broderick, A.J.; Lee, N. Word of mouth communication within online communities: Conceptualizing the online social network. J. Interact. Mark. 2007, 21, 2-20. [CrossRef]

122. Molina, A.; Gómez, M.; Martín-Consuegra, D. Tourism marketing information and destination image management. Afr. J. Bus. Manag. 2010, 4, 722-728.

123. Zhu, M.; Lai, S.Q. A study about the WOM influence on tourism destination choice. In Proceedings of the 2009 International Conference on Electronic Commerce and Business Intelligence, Beijing, China, 6-7 June 2009; pp. 120-124.

124. Lai, I.K.W.; Hitchcock, M.; Lu, D.; Liu, Y. The Influence of Word of Mouth on Tourism Destination Choice: Tourist-Resident Relationship and Safety Perception among Mainland Chinese Tourists Visiting Macau. Sustainability 2018, 10, 2114. [CrossRef]

125. Luonila, M.; Suomi, K.; Johansson, M. Creating a stir: The role of word of mouth in reputation management in the context of festivals. Scand. J. Hosp. Tour. 2016, 16, 461-483. [CrossRef]

126. Trusov, M.; Bucklin, R.E.; Pauwels, K. Effects of word-of-mouth versus traditional marketing: Findings from an internet social networking site. J. Mark. 2009, 73, 90-102. [CrossRef]

127. Shan, Y.; King, K.W. The effects of interpersonal tie strength and subjective norms on consumers' brand-related eWOM referral intentions. J. Interact. Advert. 2015, 15, 16-27. [CrossRef]

128. Gnanapala, W.A. Tourists perception and satisfaction: Implications for destination management. Am. J. Mark. Res. 2015, 1, 7-19.

129. Abbott, L. Quality and Competition; Columbia; Columbia University Press: New York, NY, USA, 1955.

130. Yan, H.; Bramwell, B. Cultural tourism, ceremony and the state in China. Ann. Tour. Res. 2008, 35, 969-989. [CrossRef]

131. Artuğer, S.; Çetinsöz, B.C.; K1lıç, İ. The effect of destination image on destination loyalty: An application in Alanya. Eur. J. Bus. Manag. 2013, 5, 124-136.

132. Esu, B.B.; Ebitu, E. Promoting an emerging tourism destination. Glob. J. Manag. Bus. Res. 2010, 10, $21-28$.

133. Lee, J.-S.; Back, K.-J. Attendee-based brand equity. Tour. Manag. 2008, 29, 331-344. [CrossRef]

134. Chambers, C.; Kouvelis, P.; Semple, J. Quality-based competition, profitability, and variable costs. Manag. Sci. 2006, 52, 1884-1895. [CrossRef]

135. Leem, M.; Hwa, J.H.; Chung, S.; Ki-Joon, B. Exploring the Roles of DMO's Social Media Efforts and Information Richness on Customer Engagement: Empirical Analysis on Facebook Event Pages. J. Travel Res. 2021, 60, 670-686.

136. Laing, J.; Frost, W. How green was my festival: Exploring challenges and opportunities associated with staging green events. Int. J. Hosp. Manag. 2010, 29, 261-267. [CrossRef]

137. Chen, C.M.; Lin, L.; Chiu, H.H. Advertising medium effect on tourist satisfaction. Ann. Tour. Res. 2016, 57, 268-272. [CrossRef]

138. Duran, E.; Hamarat, B. Festival attendees' motivations: The case of International Troia Festival. Int. J. Event Festiv. Manag. 2014, 5, 146-163. [CrossRef]

139. Sato, S.; Kim, H.; Buning, R.J.; Harada, M. Adventure tourism motivation and destination loyalty: A comparison of decision and non-decision makers. J. Destin. Mark. Manag. 2018, 8, 74-81. [CrossRef]

140. Sirakaya, E.; Petrick, J.; Choi, H.S. The role of mood on tourism product evaluations. Ann. Tour. Res. 2004, 31, 517-539. [CrossRef]

141. Yolal, M.; Gursoy, D.; Uysal, M.; Kim, H.L.; Karacaoğlu, S. Impacts of festivals and events on residents' well-being. Ann. Tour. Res. 2016, 61, 1-18. [CrossRef]

142. Chen, C.F.; Tsai, D. How destination image and evaluative factors affect behavioral intentions? Tour. Manag. 2007, $28,1115-1122$. [CrossRef]

143. Huang, H.; Liu, S.Q.; Kandampully, J.; Bujisic, M. Consumer responses to scarcity appeals in online booking. Ann. Tour. Res. 2020, 80, 102800. [CrossRef]

144. Baron, R.M.; Kenny, D.A. The moderator-mediator variable distinction in social psychological research: Conceptual, strategic, and statistical considerations. J. Personal. Soc. Psychol. 1986, 51, 1173. [CrossRef] 
145. Báez-Montenegro, A.; Devesa-Fernández, M. Motivation, satisfaction and loyalty in the case of a film festival: Differences between local and non-local participants. J. Cult. Econ. 2017, 41, 173-195. [CrossRef]

146. Liu, H.; Li, X.R.; Cárdenas, D.A.; Yang, Y. Perceived cultural distance and international destination choice: The role of destination familiarity, geographic distance, and cultural motivation. J. Destin. Mark. Manag. 2018, 9, 300-309. [CrossRef]

147. Hernández-Mogollón, J.M.; Duarte, P.A.; Folgado-Fernández, J.A. The contribution of cultural events to the formation of the cognitive and affective images of a tourist destination. J. Destin. Mark. Manag. 2018, 8, 170-178. [CrossRef]

148. Seyfi, S.; Hall, C.M.; Rasoolimanesh, S.M. Exploring memorable cultural tourism experiences. J. Herit. Tour. 2020, 15, 341-357. [CrossRef]

149. Folgado-Fernández, J.A.; Hernández-Mogollón, J.M.; Duarte, P. Destination image and loyalty development: The impact of tourists' food experiences at gastronomic events. Scand. J. Hosp. Tour. 2017, 17, 92-110. [CrossRef]

150. Bigne, E.J.; Sanchez, I.M.; Sanjez, J. Tourism image, evaluation variables and after purchase behaviour: Inter-relationship. Tour. Manag. 2001, 22, 607-616. [CrossRef]

151. Hutchinson, J.; Lai, F.; Wang, Y. Understanding the relationships of quality, value, equity, satisfaction, and behavioral intentions among golf travelers. Tour. Manag. 2009, 30, 298-308. [CrossRef]

152. Icoz, O.; Kutuk, A.; Icoz, O. Social Media and Consumer Buying Decisions in Tourism: The Case of Turkey. PASOS 2018. [CrossRef]

153. Cochran, W.G. Sampling Techniques, 3rd ed.; John Wiley \& Sons: New York, NY, USA, 1977.

154. Kock, N. Full latent growth and its use in PLS-SEM: Testing moderating relationships. Data Anal. Perspect. J. $2020,1,1-5$.

155. Kock, N. Advanced mediating effects tests, multi-group analyses, and measurement model assessments in PLS-based SEM. Int. J. E Collab. 2014, 10, 1-13. [CrossRef]

156. Kock, N. Common method bias in PLS-SEM: A full collinearity assessment approach. Int. J. E Collab. (IJEC) 2015, 11, 1-10. [CrossRef]

157. Kock, N.; Lynn, G.S. Lateral collinearity and misleading results in variance-based SEM: An illustration and recommendations. J. Assoc. Inf. Syst. 2012, 13, 546-580. [CrossRef]

158. Fornell, C.; Larcker, D.F. Evaluating structural equation models with unobservable variables and measurement error. J. Mark. Res. 1981, 18, 39-50. [CrossRef]

159. Hair, J.; Black, W.; Babin, B.; Anderson, R. Multivariate Data Analysis; Pearson: London, UK; Upper Saddle River, NJ, USA, 2010. 